\title{
Enhancing Low-Temperature Activity and Durability of Pd-based Diesel Oxidation Catalysts Using $\mathrm{ZrO}_{2}$ Supports
}

\author{
Mi-Young Kim ${ }^{\mathrm{a}}$, Eleni A. Kyriakidou ${ }^{\mathrm{a}}$, Jae-Soon Choi ${ }^{\mathrm{a}, *}$, Todd J. Toops ${ }^{\mathrm{a}}$, Andrew J. Binder ${ }^{\mathrm{a}}$, \\ Cyril Thomas $^{\mathrm{b}, \mathrm{c}}$, James E Parks II ${ }^{\mathrm{a}}$, Viviane Schwartz ${ }^{\mathrm{d}}$, Jihua Chen ${ }^{\mathrm{d}}$, Dale K. Hensley ${ }^{\mathrm{d}}$ \\ ${ }^{a}$ Fuels, Engines, and Emissions Research Center, Oak Ridge National Laboratory, Oak Ridge, TN, USA \\ ${ }^{b}$ Sorbonne Universités, UPMC Univ Paris 06, UMR 7197, Laboratoire de Réactivité de Surface, 4 Place Jussieu, \\ Case 178, F-75252, Paris, France \\ ${ }^{c}$ CNRS, UMR 7197, Laboratoire de Réactivité de Surface, 4 Place Jussieu, Case 178, F-75252, Paris, France \\ ${ }^{d}$ Center for Nanophase Materials Sciences, Oak Ridge National Laboratory, Oak Ridge, TN, USA
}

${ }^{1}$ Present address: Heesung Catalysts, 91, Somanggongwon-ro, Siheung-si, Gyeonggi-do, 429848, Republic of Korea

* Corresponding author at: Fuels, Engines, and Emissions Research Center, Oak Ridge National Laboratory, Oak Ridge, Tennessee, USA. Tel: +1 865946 1368; Fax: +1 8659461354.

E-mail address: choijs@ ornl.gov (J.-S. Choi).

Notice: This manuscript has been authored by UT-Battelle, LLC under Contract No. DE-AC0500OR22725 with the U.S. Department of Energy. The United States Government retains and the publisher, by accepting the article for publication, acknowledges that the United States Government retains a non-exclusive, paid-up, irrevocable, world-wide license to publish or reproduce the published form of this manuscript, or allow others to do so, for United States Government purposes. The Department of Energy will provide public access to these results of federally sponsored research in accordance with the DOE Public Access Plan (http://energy.gov/downloads/doe-public-access-plan). 


\begin{abstract}
We investigated the impact of $\mathrm{ZrO}_{2}$ on the performance of palladium-based oxidation catalysts with respect to low-temperature activity, hydrothermal stability, and sulfur tolerance. Pd supported on $\mathrm{ZrO}_{2}$ and $\mathrm{SiO}_{2}$ were synthesized for a comparative study. Additionally, in an attempt to maximize the $\mathrm{ZrO}_{2}$ surface area and improve sulfur tolerance, a Pd support with $\mathrm{ZrO}_{2}-$ dispersed onto $\mathrm{SiO}_{2}$ was studied. The physicochemical properties of the catalysts were examined using ICP, $\mathrm{N}_{2}$ sorption, XRD, SEM, TEM, and $\mathrm{NH}_{3^{-}}, \mathrm{CO}_{2^{-}}$, and $\mathrm{NO}_{\mathrm{x}}-\mathrm{TPD}$. The activity of the $\mathrm{Pd}$ catalysts were measured from 60 to $600{ }^{\circ} \mathrm{C}$ in a flow of $4000 \mathrm{ppm} \mathrm{CO}, 500 \mathrm{ppm} \mathrm{NO}, 1000$ ppm $\mathrm{C}_{3} \mathrm{H}_{6}, 4 \% \mathrm{O}_{2}, 5 \% \mathrm{H}_{2} \mathrm{O}$, and Ar balance. The Pd catalysts were evaluated in fresh, sulfated, and hydrothermally aged states.. Overall, the $\mathrm{ZrO}_{2}$-containing catalysts showed considerably higher $\mathrm{CO}$ and $\mathrm{C}_{3} \mathrm{H}_{6}$ oxidation activity than $\mathrm{Pd} / \mathrm{SiO}_{2}$ under the reaction conditions studied. The good performance of $\mathrm{ZrO}_{2}$-containing catalysts appeared to be due in part to high $\mathrm{Pd}$ dispersion resulting from strong Pd and support interaction. Another beneficial effect of strong interaction between $\mathrm{Pd}$ and $\mathrm{ZrO}_{2}$ was manifested as a greater hydrothermal stability with good oxidation activity even after aging at 800 and $900{ }^{\circ} \mathrm{C}$ for $16 \mathrm{~h}$. In contrast, $\mathrm{Pd} / \mathrm{SiO}_{2}$ suffered significant performance loss due to $\mathrm{Pd}$ particle coarsening. Although the $\mathrm{Pd} / \mathrm{ZrO}_{2}-\mathrm{SiO}_{2}$ catalyst was not more active than $\mathrm{Pd} / \mathrm{ZrO}_{2}$, improved tolerance to sulfur was realized. Unlike the bulk $\mathrm{ZrO}_{2}$ support, the $\mathrm{ZrO}_{2}$-incorporated $\mathrm{SiO}_{2}$ presented only weak basicity leading to a superior sulfur tolerance of $\mathrm{Pd} / \mathrm{ZrO}_{2}-\mathrm{SiO}_{2}$. These results confirmed the potential of developing Pd-based oxidation catalysts with enhanced low-temperature activity and durability using $\mathrm{ZrO}_{2}-\mathrm{SiO}_{2}$ supports. Controlling morphology and accessible area of the dispersed $\mathrm{ZrO}_{2}$ layer appeared critical to further maximize the catalytic performance.
\end{abstract}

Keywords: Diesel oxidation catalyst; palladium; zirconia; support; sol-gel.

\title{
1. Introduction
}

With ever tightening automotive emission standards, the role of oxidation catalysts becomes increasingly more important to remove $\mathrm{CO}$ and unburned hydrocarbons ( $\mathrm{HCs}$ ) from the engine exhaust gas as well as to enhance the performance of downstream $\mathrm{NO}_{\mathrm{x}}$ control catalysts [1-3]. Moreover, as the efficiency of internal combustion engines is required to improve in response to US EPA's Corporate Average Fuel Economy (CAFE) mandates, the average exhaust gas 
temperature decreases making it more and more challenging to maintain high performance of aftertreatment catalysts. To comply with the future emission and fuel economy regulations, automotive catalysts should therefore achieve catalyst light-off (50\% or higher conversion) at temperatures significantly lower than the current state of the art.

Despite recent progress made in the low-temperature catalyst development with novel formulations such as $\mathrm{Au}$ and $\mathrm{Ag}$ nanoparticles supported on metal oxides [4-7], critical challenges remain in implementing these novel materials into practice. For instance, new catalysts should be able to maintain high activity under harsh real automotive environments with good thermal stability and resistance to poisons [8,9]. Due to relatively good stability and activity, $\mathrm{Pt}$ and/or $\mathrm{Pd}$ supported on $\mathrm{CeO}_{2}-\mathrm{ZrO}_{2}$ added $\mathrm{Al}_{2} \mathrm{O}_{3}$ supports have been widely used as commercial oxidation catalysts [1,10]. The high affinity of $\mathrm{Al}_{2} \mathrm{O}_{3}$ toward sulfur, however, can lead to the formation of $\mathrm{Al}_{2}\left(\mathrm{SO}_{4}\right)_{3}$ with resultant performance degradation [11]. In addition, repeated high-temperature desulfation can lead to gradual sintering of metal components with resultant permanent activity loss. To further enhance the low-temperature activity and stability of Pt and Pd catalysts, recent research efforts have been devoted to developing novel approaches including the use of $\mathrm{FeO}_{\mathrm{x}}$ as a support [12-14] and the encapsulation in core-shell nanostructures $[15,16]$.

We have recently reported that $\mathrm{Pt}$ particles supported on $\mathrm{ZrO}_{2}$-modifed $\mathrm{SiO}_{2}$ were excellent $\mathrm{CO}$ oxidation catalysts with promising low-temperature activity, hydrothermal stability, and sulfur tolerance [17]. Covering $\mathrm{SiO}_{2}$ surfaces with $\mathrm{ZrO}_{2}$ via sol-gel method before $\mathrm{Pt}$ impregnation led to good dispersion and hydrothermal stability of Pt particles due to strong interaction between $\mathrm{Pt}$ and $\mathrm{ZrO}_{2}$ phases. Furthermore, $\mathrm{ZrO}_{2}$ incorporation generated surface acidity but negligible basicity, which explained the relatively low and weak sulfur uptake observed on $\mathrm{Pt} / \mathrm{ZrO}_{2}-\mathrm{SiO}_{2}$. We also revealed that $\mathrm{ZrO}_{2}$ increased the oxygen affinity of $\mathrm{Pt}$ leading to good catalytic activity of $\mathrm{Pt} / \mathrm{ZrO}_{2}-\mathrm{SiO}_{2}$ in $\mathrm{CO}$ oxidation. In the present study, we extended this $\mathrm{ZrO}_{2}$-incorporated $\mathrm{SiO}_{2}$ support concept to $\mathrm{Pd}$, a commonly-employed automotive catalyst that is traditionally less expensive than $\mathrm{Pt}$ by a factor of 2-3. For comparison, the catalytic properties of $\mathrm{Pd} / \mathrm{ZrO}_{2}$ and $\mathrm{Pd} / \mathrm{SiO}_{2}$ were studied. This paper will show that, as in the case of $\mathrm{Pt}, \mathrm{ZrO}_{2}$ incorporation on $\mathrm{SiO}_{2}$ has positive effects on $\mathrm{Pd}$ as well with good metal dispersion, hydrothermal stability, sulfur tolerance, and $\mathrm{CO}$ and $\mathrm{C}_{3} \mathrm{H}_{6}$ oxidation activity. 
Directions for future research will be discussed to facilitate the development of strategies to maximize the potential of $\mathrm{ZrO}_{2}$ supports.

\section{Experimental}

\subsection{Preparation of Pd Catalysts}

Amorphous silica gel (Davisil Grade 635, pore size $60 \AA$ A, 60-100 mesh, Sigma-Aldrich) was used as a support for the preparation of Pd catalysts. $\mathrm{ZrO}_{2}$ was incorporated on the silica surface following the procedure described in previous papers [17,18]. $\mathrm{SiO}_{2}$ was first dehydrated with anhydrous ethanol (200 proof, ACS reagent, $\geq 99.5 \%$, Sigma-Aldrich) and reacted at $80{ }^{\circ} \mathrm{C}$ for 3 h with zirconium(IV) n-propoxide (70\% $w / w$ in $n$-propanol, Alfa Aesar) dissolved in ethanol. The ratio between $\mathrm{SiO}_{2}, \mathrm{Zr}$ precursor solution, and ethanol was $1: 2: 16$ on a weight basis. The amount of $\mathrm{Zr}$ precursor molecules in the mixture corresponded to an average silanol concentration on the $\mathrm{SiO}_{2}$ surface assumed to be $7.5 \mu \mathrm{mol} / \mathrm{m}^{2}$ based on [19]. Since more than 1 silanol group would have reacted with a $\mathrm{Zr}$ precursor molecule during the sol-gel process, unreacted $\mathrm{Zr}$ precursor molecules were removed through ethanol washing. Subsequently, the filtrates were dried at $100{ }^{\circ} \mathrm{C}$ overnight and calcined at $500{ }^{\circ} \mathrm{C}$ for $2 \mathrm{~h}$. The resulting $\mathrm{ZrO}_{2}-\mathrm{SiO}_{2}$ support was impregnated with a palladium (II) nitrate solution (12 16 w/w, Alfa Aesar) by incipient wetness method to obtain a $1 \mathrm{wt} \% \mathrm{Pd}$ loading. After the impregnation, the catalyst was dried at $100{ }^{\circ} \mathrm{C}$ in air and reduced in a flow of $10 \% \mathrm{H}_{2}$ in $\mathrm{Ar}$ at $500{ }^{\circ} \mathrm{C}$ for $2 \mathrm{~h}$. The as-prepared catalyst was named as $\mathrm{Pd} / \mathrm{ZrO}_{2}-\mathrm{SiO}_{2}$. For comparison, $\mathrm{Pd}$ catalysts supported on bare $\mathrm{SiO}_{2}$ $\left(\mathrm{Pd} / \mathrm{SiO}_{2}\right)$ and $\mathrm{ZrO}_{2}\left(\mathrm{Pd} / \mathrm{ZrO}_{2} ; \mathrm{ZrO}_{2}\right.$ from Saint-Gobain) were also prepared by incipient wetness method (1 wt \% loading).

\subsection{Characterization}

The $\mathrm{Zr}$ and $\mathrm{Pd}$ contents of the prepared catalysts were determined using Inductively Coupled Plasma-Atomic Emission Spectrometry (ICP-AES; Optima 4300 DV, Perkin-Elmer, USA). The surface area and porosity of catalysts were determined using an automatic volumetric adsorption apparatus (Autosorb-1, Quantachrome, USA). The samples were evacuated at $200{ }^{\circ} \mathrm{C}$ for $2 \mathrm{~h}$ prior to exposure to nitrogen gas. Surface areas were calculated using the Brunauer-Emmett- 
Teller (BET) equation and the pore volumes and average pore sizes were determined using the Barrett-Joyner-Halenda (BJH) method.

In powder XRD, the catalysts were ground into fine powder and placed on a zero background carbon plate of approximately $3.8 \mathrm{~cm}$ in diameter. The X-ray diffraction patterns of catalysts were recorded on a powder X-ray Diffractometer (XRD; X'Pert PRO, PANalytical, The Netherlands) operated at $45 \mathrm{kV}$ and $40 \mathrm{~mA}$ using $\mathrm{CuK \alpha}$ radiation $\left(K_{\alpha}=0.154178 \mathrm{~nm}\right)$ over a $2 \theta$ angle of 5-50 in a scan mode of $0.02^{\circ}$ in $2 \mathrm{~s}$.

A Transmission Electron Microscope (TEM; LIBRA-120, Carl Zeiss, Germany) equipped with $\mathrm{L} \mathrm{LaB}_{6}$ filament was employed to examine the Pd dispersion. The acceleration voltage was $120 \mathrm{kV}$. The TEM samples were prepared by dropping ethanol suspension of Pd catalysts on a copper grid. The particle size of Pd was estimated from the digitized TEM image using analysis software (ImageJ, NIH, USA). The Scanning Electron Microscope (SEM; Merlin, Carl Zeiss, Germany) analyses were performed to examine the morphology of Pd catalysts, operating at an accelerating voltage of $30 \mathrm{kV}$. Elemental mapping analyses were also performed using Energy Dispersive X-ray Spectroscopy (EDS; Bruker Nano Gmbh with a XFlash 5030 detector, Germany) attached to the SEM.

$\mathrm{NH}_{3}$ - and $\mathrm{CO}_{2}$-Temperature-Programmed Desorption (TPD) experiments were carried out with a flow reactor system. For each TPD experiment, $0.1 \mathrm{~g}$ of catalyst was placed between two quartz wool plugs in a U-shaped quartz tube ( $8 \mathrm{~mm}$ I.D.) and pretreated at $600{ }^{\circ} \mathrm{C}$ for $0.5 \mathrm{~h}$ in an Ar flow. After cooling to $100{ }^{\circ} \mathrm{C}$, the catalyst was exposed to a flow of $2500 \mathrm{ppm} \mathrm{NH}_{3}$ in $\mathrm{Ar}$ for $1 \mathrm{~h}$, then to an Ar flow for $1 \mathrm{~h}$. Desorption was carried out in an Ar flow from 100 to $600{ }^{\circ} \mathrm{C}$ with a temperature ramping rate of $10{ }^{\circ} \mathrm{C} / \mathrm{min}$. The total flow rate was $50 \mathrm{~mL} / \mathrm{min}$ (STP) for all the steps. The procedure for the $\mathrm{CO}_{2}$-TPD experiments was identical except that the adsorption was done in a flow of $1 \% \mathrm{CO}_{2}$ in $\mathrm{Ar}$ at $50{ }^{\circ} \mathrm{C}$ followed by a $1 \mathrm{~h}$ purge with the total flow rate of $100 \mathrm{~mL} / \mathrm{min}$ (STP). Gas composition was continuously analyzed by a quadrupole mass spectrometer (RGA100, SRS, USA). The $m / z$ values monitored were 15 for $\mathrm{NH}_{3}$ and 44 for $\mathrm{CO}_{2}$.

$\mathrm{NO}_{\mathrm{x}}$-TPD experiments were performed in a $\mathrm{U}$-shaped quartz reactor (15 mm I.D.). The details were introduced in $[20,21]$. The catalysts were pretreated in a $20 \% \mathrm{O}_{2} / \mathrm{He}$ flow at $500{ }^{\circ} \mathrm{C}$ for $2 \mathrm{~h}$ with a flow rate of $100 \mathrm{~mL} / \mathrm{min}$. After cooling to room temperature, the catalysts were exposed to the adsorption mixture which consisted of $400 \mathrm{ppm} \mathrm{NO}$ and $8 \% \mathrm{O}_{2}$ in $\mathrm{He}$. $\mathrm{NO}_{\mathrm{x}}-\mathrm{TPD}$ experiments were performed from room temperature to $560{ }^{\circ} \mathrm{C}$ at a heating rate of $3{ }^{\circ} \mathrm{C} / \mathrm{min}$ 
under a mixture of $8 \% \mathrm{O}_{2}$ in $\mathrm{He}$ with a total flow rate of $230 \mathrm{~mL} / \mathrm{min}$ (STP). The gas composition was continuously monitored at reactor outlet by a chemiluminescence $\mathrm{NO}_{\mathrm{x}}$ analyzer (42C-HT, Thermo Environmental Instruments). The NOx-TPD profiles were corrected for the weight loss due to dehydration of the samples.

\subsection{Evaluation of Catalytic Performance in Oxidation Reactions}

The catalytic performance of the prepared catalysts was evaluated for $\mathrm{CO}$ and $\mathrm{C}_{3} \mathrm{H}_{6}$ oxidation activity under simulated diesel exhaust conditions. A flow reactor equipped with a quadrupole mass spectrometer (RGA100, SRS, USA) was employed. As previously described in [22], it has two gas banks controlled by a 4-way valve and a bypass line for flow equilibration and calibration. The gas flow rates were adjusted with mass flow controllers and the furnace temperature was controlled by a PID temperature controller. For each reactor run, $0.1 \mathrm{~g}$ of Pd catalyst was positioned between two plugs of quartz wool in a U-shaped quartz tube. Prior to the experiments, the catalysts were pretreated in an Ar flow at $600{ }^{\circ} \mathrm{C}$ for $1 \mathrm{~h}$. The reactant gas mixture consisting of 4000 ppm CO, $1000 \mathrm{ppm}_{3} \mathrm{H}_{6}, 500 \mathrm{ppm} \mathrm{NO}, 4 \% \mathrm{O}_{2}, 5 \% \mathrm{H}_{2} \mathrm{O}$, and $\mathrm{Ar}$ balance was fed into the reactor at a total flow rate of $200 \mathrm{~mL} / \mathrm{min}$ (STP). The performance was evaluated by continuously increasing the reaction temperature from 60 to $600{ }^{\circ} \mathrm{C}$ at $5{ }^{\circ} \mathrm{C} / \mathrm{min}$. The effluent gas composition was analyzed with the mass spectrometer. The monitored $\mathrm{m} / \mathrm{z}$, ratios were 26 for $\mathrm{C}_{3} \mathrm{H}_{6}, 28$ for $\mathrm{CO}$, and 44 for $\mathrm{CO}_{2}$. To obtain $\mathrm{CO}$ concentration values, the contribution from $\mathrm{CO}_{2}$ fragmentation at $\mathrm{m} / \mathrm{z} 28$ was taken into account. Several consecutive oxidation runs were performed for each catalyst in the order of fresh, sulfated, desulfated, and hydrothermally aged states.

Following the fresh-state performance evaluation, the catalyst was sulfated at $400{ }^{\circ} \mathrm{C}$ in 50 ppm $\mathrm{SO}_{2}, 5 \% \mathrm{H}_{2} \mathrm{O}, 4 \% \mathrm{O}_{2}$, and Ar balance for $3 \mathrm{~h}$. After sulfation, all weakly bound sulfur

species were removed by shutting off the $\mathrm{SO}_{2}$ flow and purging at $400{ }^{\circ} \mathrm{C}$ for 30 min before another reactor evaluation. The sulfur exposed catalysts were then desulfated consecutively at 600,700 and $800{ }^{\circ} \mathrm{C}$ (temperature ramp from $400{ }^{\circ} \mathrm{C}$ at $5{ }^{\circ} \mathrm{C} / \mathrm{min}$ ) for $1 \mathrm{~h}$ in a rich phase gas mixture including $1 \% \mathrm{H}_{2}, 5 \% \mathrm{H}_{2} \mathrm{O}$, and Ar balance. After each desulfation step and prior to further evaluation, the samples were pretreated at $600{ }^{\circ} \mathrm{C}$ in $4 \% \mathrm{O}_{2}, 5 \% \mathrm{H}_{2} \mathrm{O}$, and Ar balance for 1 h. For sulfur analysis, a fluorescent $\mathrm{SO}_{2}$ analyzer (100 A UV fluorescence $\mathrm{SO}_{2}$ analyzer, Teledyne API, San Diego, CA, USA) was used. A second reactor loaded with an oxidation 
$\mathrm{Pt} / \mathrm{SiO}_{2}$ catalyst was placed downstream of the main reactor to oxidize any $\mathrm{H}_{2} \mathrm{~S}$ to $\mathrm{SO}_{2}$, since the sulfur analyzer detected only $\mathrm{SO}_{2}$ [23]; a stream of $\mathrm{O}_{2}$ was introduced after the main reactor, but before the second reactor to allow this oxidation. Assuming a thermodynamic equilibrium between $\mathrm{SO}_{2}$ and $\mathrm{SO}_{3}$ was reached over the downstream reactor operated at $700{ }^{\circ} \mathrm{C}$, the total sulfur concentration could be determined (i.e., $\mathrm{SO}_{2}+\mathrm{SO}_{3}+\mathrm{H}_{2} \mathrm{~S}$ ).

Following the sulfation/desulfation study, the catalysts were hydrothermally aged at $800{ }^{\circ} \mathrm{C}$ for $16 \mathrm{~h}$ in a flow of $10 \% \mathrm{O}_{2}, 5 \% \mathrm{H}_{2} \mathrm{O}$, and Ar balance. After a performance evaluation run, the catalysts were further aged at $900{ }^{\circ} \mathrm{C}$ for $16 \mathrm{~h}$ in the same flow used for the $800{ }^{\circ} \mathrm{C}$ aging.

\section{Results and Discussion}

\subsection{Catalyst Characterization}

Table 1 lists the chemical composition and some physical properties of Pd catalysts. The target Pd loading was $1 \mathrm{wt} \%$ and actual values determined by ICP were ca. $1.1 \mathrm{wt} \%$. The surface area of $\mathrm{Pd} / \mathrm{ZrO}_{2}, \mathrm{Pd} / \mathrm{SiO}_{2}$, and $\mathrm{Pd} / \mathrm{ZrO}_{2}-\mathrm{SiO}_{2}$ was, respectively, 93, 447, and $404 \mathrm{~m}^{2} / \mathrm{g}$ at the fresh state and 24,301 , and $325 \mathrm{~m}^{2} / \mathrm{g}$ after the aging at $800{ }^{\circ} \mathrm{C}$ for $16 \mathrm{~h}$. The fact that the surface area of $\mathrm{Pd} / \mathrm{ZrO}_{2}-\mathrm{SiO}_{2}$ was almost identical to that of $\mathrm{Pd} / \mathrm{SiO}_{2}$ indicates that thin layers and/or small particles of $\mathrm{ZrO}_{2}$ were formed on $\mathrm{SiO}_{2}$ surfaces. The slight decrease in surface area reported per $\mathrm{g}$ of sample is expected since $\mathrm{ZrO}_{2}$ is heavier than $\mathrm{SiO}_{2}$. The surface area for $\mathrm{Pd} / \mathrm{ZrO}_{2}-\mathrm{SiO}_{2}$ would be $483 \mathrm{~m}^{2} / \mathrm{g}_{\mathrm{SiO} 2}$ compared to $447 \mathrm{~m}^{2} / \mathrm{g}$ for $\mathrm{SiO}_{2}$, suggesting that $\mathrm{ZrO}_{2}$ also contributed in developing surface area and that it is not just a coverage of $\mathrm{SiO}_{2}$. The surface area and pore volume of all Pd catalysts decreased after hydrothermal aging suggesting significant structural changes such as crystallization, particle growth, pore blocking and pore wall collapse. Nevertheless, a $\mathrm{ZrO}_{2}$-induced stabilization of the $\mathrm{SiO}_{2}$ surface area can be seen in the $\mathrm{Pd} / \mathrm{ZrO}_{2}$ $\mathrm{SiO}_{2}$ hydrothermally-aged data. Indeed, the surface area and porosity loss for the $\mathrm{Pd} / \mathrm{ZrO}_{2}-\mathrm{SiO}_{2}$ were smaller than those of $\mathrm{Pd} / \mathrm{SiO}_{2}$ and $\mathrm{Pt} / \mathrm{ZrO}_{2}$. These results indicate that the addition of $\mathrm{ZrO}_{2}$ to $\mathrm{SiO}_{2}$ can lead to a more stable support compared to bulk $\mathrm{SiO}_{2}$ or $\mathrm{ZrO}_{2}$.

The $\mathrm{N}_{2}$ adsorption-desorption isotherms for Pd catalysts are represented in Fig. 1. The Pd catalysts supported on $\mathrm{SiO}_{2}$ and $\mathrm{ZrO}_{2}-\mathrm{SiO}_{2}$ exhibited typical Type IV isotherms [24] with a hysteresis loop associated with capillary condensation in mesopores at both fresh and aged state. The $\mathrm{Pd} / \mathrm{ZrO}_{2}$ in fresh state also showed a similar behavior. By contrast, the aged $\mathrm{Pd} / \mathrm{ZrO}_{2}$ showed 
$\mathrm{N}_{2}$ isotherms with a negligible "knee" point and presented a wide pore size distribution. The lack of knee point represents weak adsorbate-adsorbent interaction resulting in low BET surface area. This indicates that physical properties of $\mathrm{Pd} / \mathrm{ZrO}_{2}$ were more severely affected by hydrothermal aging than those of $\mathrm{Pd} / \mathrm{SiO}_{2}$ and $\mathrm{Pd} / \mathrm{ZrO}_{2}-\mathrm{SiO}_{2}$.

$\mathrm{X}$-ray diffraction patterns were recorded for each sample to investigate both crystallographic phases present and their crystallinity (Fig. 2). $\mathrm{Pd} / \mathrm{ZrO}_{2}$ sample showed diffraction peaks corresponding to a monoclinic $\mathrm{ZrO}_{2}$ at 17.4, 24.0, 28.2, 31.4, 34.1, 35.3, 40.7, 44.8, 45.5 and $48.9^{\circ}$ (ICDD\# 00-024-1165). The peaks grew with increasing the aging temperature indicating $\mathrm{ZrO}_{2}$ particle aggregation which is consistent with the $\mathrm{N}_{2}$ sorption data. The relatively weak thermal stability of the monoclinic $\mathrm{ZrO}_{2}$ phases is well-known and could be a significant challenge to overcome for very demanding automotive applications [25]. No significant diffraction peaks associated with $\mathrm{Pd}$ or $\mathrm{PdO}$ were observed. In general, the peaks related to cubic Pd particles should appear at $2 \theta$ of 39.0, 40.1 and $46.6^{\circ}$ (ICDD\# 01-087-0637 and ICDD\# 00046-1043), while the (101) plane of tetragonal PdO is found at $2 \theta$ of $33.8^{\circ}$ (ICDD\# 04-0024417) (see the two areas marked with red boxes in Fig.2). The absence of Pd peaks on $\mathrm{Pd} / \mathrm{ZrO}$ suggests that Pd was well dispersed due to strong interaction between the metal and support. Considering the large impact of aging on the $\mathrm{ZrO}_{2}$ support this lack of impact on the $\mathrm{Pd}$ particles are surprising. In contrast, $\mathrm{Pd} / \mathrm{SiO}_{2}$ exhibited peaks attributable to $\mathrm{Pd}$ and $\mathrm{PdO}$ particles after aging at $900{ }^{\circ} \mathrm{C}$; the broad peak at $2 \theta$ of $22^{\circ}$ corresponded to amorphous $\mathrm{SiO}_{2}$ structure. The fresh $\mathrm{Pd} / \mathrm{ZrO}_{2}-\mathrm{SiO}_{2}$ presented a small peak of $\mathrm{PdO}$ at $33.8^{\circ}$. The $\mathrm{PdO}$ peak became sharper with aging at $800{ }^{\circ} \mathrm{C}$ of $\mathrm{Pd} / \mathrm{ZrO}_{2}-\mathrm{SiO}_{2}$. After the aging at $900{ }^{\circ} \mathrm{C}, \mathrm{Pd}$ metal-attributable peaks also appeared; the broad peak at $30^{\circ}$ is attributable to a cubic $\mathrm{ZrO}_{2}$ phase (ICDD\# 00-003-0640). The smaller $\mathrm{Pd}$ peaks on $\mathrm{Pd} / \mathrm{ZrO}_{2}-\mathrm{SiO}_{2}$ than $\mathrm{Pd} / \mathrm{SiO}_{2}$ on the aged state at $900{ }^{\circ} \mathrm{C}$ suggests that the addition of $\mathrm{ZrO}_{2}$ on $\mathrm{SiO}_{2}$ increased Pd-support interactions.

Transmission electron microscopy images and particle size distributions in Fig. 3 show clear differences in the size of Pd particles among samples. Average Pd particle sizes are listed in Table 1. No Pd particles were observed by TEM on $\mathrm{Pd} / \mathrm{ZrO}_{2}$ in the fresh state due to a very high Pd dispersion. After aging at $800{ }^{\circ} \mathrm{C}$, the Pd particles with the average size of $1.1 \mathrm{~nm}$ were detected. This means that although the hydrothermal aging induced a considerable decrease in surface area, the $\mathrm{ZrO}_{2}$ support was still able to maintain a high Pd dispersion. In the case of $\mathrm{Pd} / \mathrm{SiO}_{2}$ and $\mathrm{Pd} / \mathrm{ZrO}_{2}-\mathrm{SiO}_{2}, \mathrm{Pd}$ particles in the range from $1 \mathrm{~nm}$ to $12 \mathrm{~nm}$ were observed. 
Contrary to the previously published results on Pt catalysts [17], the fresh $\mathrm{Pd} / \mathrm{SiO}_{2}$ had smaller $\mathrm{Pd}$ particles than the fresh $\mathrm{Pd} / \mathrm{ZrO}_{2}-\mathrm{SiO}_{2}$ with an average value of $2.4 \mathrm{~nm}$. Pd particles on $\mathrm{SiO}_{2}$ were, however, more prone to sintering during hydrothermal again at $800{ }^{\circ} \mathrm{C}$. In fact, the average $\mathrm{Pd}$ particle size on $\mathrm{ZrO}_{2}-\mathrm{SiO}_{2}$ decreased with aging at $800{ }^{\circ} \mathrm{C}$. We conjecture that a portion of $\mathrm{Pd}$ atoms initially deposited on exposed $\mathrm{SiO}_{2}$ surfaces with weaker metal-support interaction migrated onto $\mathrm{ZrO}_{2}$ surfaces during the aging step and stabilized as smaller particles on $\mathrm{ZrO}_{2}$ surfaces of the $\mathrm{ZrO}_{2}-\mathrm{SiO}_{2}$ support achieving a higher Pd dispersion after the aging. Further research is, however, needed to support this hypothesis and more clearly explain this unexpected behavior for instance using $\mathrm{H}_{2}$ chemisorption.

Fig. 4 shows SEM images and EDX Pd maps of the catalysts aged at $900{ }^{\circ} \mathrm{C}$. Pd particles were still well-dispersed on $\mathrm{Pd} / \mathrm{ZrO}_{2}$, while large aggregates were observed on both $\mathrm{Pd} / \mathrm{SiO}_{2}$ and $\mathrm{Pd} / \mathrm{ZrO}_{2}-\mathrm{SiO}_{2}$ catalysts. The large aggregates observed on $\mathrm{Pd} / \mathrm{ZrO}_{2}-\mathrm{SiO}_{2}$ were more likely concentrated on exposed $\mathrm{SiO}_{2}$ surfaces (i.e., not coated by $\mathrm{ZrO}_{2}$ ) as those aggregate-containing regions presented lower $\mathrm{Zr} / \mathrm{Si}$ ratio than other regions with fewer Pd aggregates (data not shown). This is consistent with the above TEM data.

The extent of $\mathrm{SiO}_{2}$ surface coverage by $\mathrm{ZrO}_{2}$ was estimated using $\mathrm{NO}_{\mathrm{x}}$-TPD to better understand the effectiveness of the sol-gel method employed as well as the observed performance trends. It has previously been demonstrated by Thomas et al. that $\mathrm{NO}_{x}$ chemisorption selectively occurs on $\mathrm{ZrO}_{2}$ and not on $\mathrm{SiO}_{2}$ or tungstates [20,21], which makes $\mathrm{NO}_{\mathrm{X}}$-TPD a reliable tool to estimate the accessible zirconia surface area of a variety of $\mathrm{ZrO}_{2}$ containing materials $[20,21]$. The $\mathrm{NO}_{\mathrm{x}}-\mathrm{TPD}$ profiles of $\mathrm{Pd} / \mathrm{ZrO}_{2}$ and $\mathrm{Pd} / \mathrm{ZrO}_{2}-\mathrm{SiO}_{2}$ are shown in Fig. 5 and the corresponding data are summarized in Table 2. The $\mathrm{NO}_{x}$-TPD profiles obtained on the fresh $\mathrm{ZrO}_{2}$ support closely resembled to those found earlier [21] showing well-resolved low and high temperature (LT: $85^{\circ} \mathrm{C}$ and $\mathrm{HT}: 420{ }^{\circ} \mathrm{C}$ ) $\mathrm{NO}_{\mathrm{x}}$ desorption peaks (not shown). As already noticed recently in the case of the introduction of $\mathrm{Rh}$ on tungstated $\mathrm{Ce}_{0.68} \mathrm{Zr}_{0.32} \mathrm{O}_{2}$ materials [26], the introduction of Pd significantly decreased the resolution of the LT and HT desorption peaks on fresh $\mathrm{Pd} / \mathrm{ZrO}_{2}$ (Fig .5), with the desorption of $\mathrm{NO}_{x}$ species at intermediate temperatures (120$\left.250{ }^{\circ} \mathrm{C}\right)$ and a shift of the HT peak to slightly lower temperature $\left(400{ }^{\circ} \mathrm{C}\right)$. In contrast, the introduction of $\mathrm{Pd}$ on $\mathrm{ZrO}_{2}-\mathrm{SiO}_{2}$ did not decrease the resolution of the LT and HT desorption peaks as much as in the case of fresh $\mathrm{Pd} / \mathrm{ZrO}_{2}$ (Fig. 5) suggesting that $\mathrm{Pd}$ would have been deposited on exposed $\mathrm{SiO}_{2}$ surfaces (i.e., not coated by $\mathrm{ZrO}_{2}$ ) as well in agreement with the 
TEM, SEM and EDX results. It is remarkable that $\mathrm{NO}_{\mathrm{x}}$ desorption behavior on $\mathrm{ZrO}_{2}-\mathrm{SiO}_{2}$ was quite different from that of bulk $\mathrm{ZrO}_{2}$ support. For example, the LT and $\mathrm{HT}$ peaks of $\mathrm{Pd} / \mathrm{ZrO}_{2}$ were observed at $90{ }^{\circ} \mathrm{C}$ and $400{ }^{\circ} \mathrm{C}$, while those of $\mathrm{Pd} / \mathrm{ZrO}_{2}-\mathrm{SiO}_{2}$ appeared at $85{ }^{\circ} \mathrm{C}$ and $325{ }^{\circ} \mathrm{C}$ in the fresh state. Furthermore, while the intensity of LT peak was lower than that of HT peak on the fresh $\mathrm{Pd} / \mathrm{ZrO}_{2}$, the intensity of LT peak was higher than that of HT peak on the fresh $\mathrm{Pd} / \mathrm{ZrO}_{2}-\mathrm{SiO}_{2}$. We can thus conclude that $\mathrm{Pd} / \mathrm{ZrO}_{2}$ had overall more stable $\mathrm{NO}_{\mathrm{x}}$ species adsorbed on the surface than $\mathrm{Pd} / \mathrm{ZrO}_{2}-\mathrm{SiO}_{2}$ presumably due to stronger surface basicity as will be supported later by $\mathrm{CO}_{2}$-TPD results. The $\mathrm{NO}_{\mathrm{x}}$ uptake of the fresh $\mathrm{Pd} / \mathrm{ZrO}_{2}$ and $\mathrm{Pd} / \mathrm{ZrO}_{2}-\mathrm{SiO}_{2}$ was 495 and $327 \mu \mathrm{mol} / \mathrm{g}$, respectively. These correspond to an accessible $\mathrm{ZrO}_{2}$ surface area of 83 $\mathrm{m}^{2} / \mathrm{g}$ for $\mathrm{Pd} / \mathrm{ZrO}_{2}$ and $54 \mathrm{~m}^{2} / \mathrm{g}$ for $\mathrm{Pd} / \mathrm{ZrO}_{2}-\mathrm{SiO}_{2}$. By comparing the BET surface area of $\mathrm{Pd} / \mathrm{ZrO}_{2}-\mathrm{SiO}_{2}$ with the accessible $\mathrm{ZrO}_{2}$ surface area determined by $\mathrm{NO}_{\mathrm{x}} \mathrm{TPD}$, it is possible to estimate that at most about $13 \%$ of $\mathrm{SiO}_{2}$ surface was covered by $\mathrm{ZrO}_{2}$. Considering that the $\mathrm{Zr}$ loading of $12.1 \mathrm{wt} \%$ achieved in this work (see Table 1) is close to the amount of $\mathrm{Zr}$ precursor needed to form a monolayer of $\mathrm{ZrO}_{\mathrm{x}}$ in a silanol group to $\mathrm{Zr}$ precursor ratio of 2, and that there was an excess $\mathrm{Zr}$ precursor in the sol-gel synthesis mixture (see Experimental), it is likely that anchored $\mathrm{Zr}$ species underwent major agglomeration during calcination exposing a large fraction of $\mathrm{SiO}_{2}$ surface. After the aging at $800{ }^{\circ} \mathrm{C}, \mathrm{NO}_{\mathrm{x}}$ uptake for both catalysts drastically decreased with $\mathrm{ZrO}_{2}$ surface area of 25 and $8 \mathrm{~m}^{2} / \mathrm{g}$ for $\mathrm{Pd} / \mathrm{ZrO}_{2}$ and $\mathrm{Pd} / \mathrm{ZrO}_{2}-\mathrm{SiO}_{2}$, respectively. Note that $\mathrm{Pd} / \mathrm{ZrO}_{2}$ maintained a higher $\mathrm{ZrO}_{2}$ surface area advantage over $\mathrm{Pd} / \mathrm{ZrO}_{2}-\mathrm{SiO}_{2}$ despite the fact that the latter had a much larger BET surface area. Considering the absence of well crystalline $\mathrm{ZrO}_{2}$ phases in the XRD patterns (Fig. 2), it is likely that structural changes occurred in $\mathrm{SiO}_{2}$ during the hydrothermal aging (such as pore blockage) limiting the access to $\mathrm{ZrO}_{2}$ surfaces. We hypothesize that a higher $\mathrm{SiO}_{2}$ coverage by $\mathrm{ZrO}_{2}$ could mitigate the $\mathrm{SiO}_{2}$ structure evolution, which would in turn minimize loss in accessible $\mathrm{ZrO}_{2}$ surface area. The $\mathrm{ZrO}_{2}$ particle sizes estimated from $\mathrm{NO}_{\mathrm{x}}$ uptake are listed in Table 2. The $\mathrm{ZrO}_{2}$ particle sizes of $\mathrm{Pd} / \mathrm{ZrO}_{2}$ and $\mathrm{Pd} / \mathrm{ZrO}_{2}-\mathrm{SiO}_{2}$ were, respectively, 12 and $3 \mathrm{~nm}$ in the fresh state, and 41 and $21 \mathrm{~nm}$ after aging at $800{ }^{\circ} \mathrm{C}$. The $\mathrm{ZrO}_{2}$ particle sizes calculated from $\mathrm{NO}_{\mathrm{x}}-\mathrm{TPD}$ and XRD (Scherrer equation) were similar for the fresh $\mathrm{Pd} / \mathrm{ZrO}_{2}$, but significantly different for the aged $\mathrm{Pd} / \mathrm{ZrO}_{2}$ possibly due to lattice distortion occurred during the high temperature aging. The absence of $\mathrm{ZrO}_{2}$-attributable XRD peaks made it impossible to estimate the $\mathrm{ZrO}_{2}$ crystallite size for the $\mathrm{Pd} / \mathrm{ZrO}_{2}-\mathrm{SiO}_{2}$ catalysts. 
It has been reported that high surface acidity and low basicity can confer high sulfur tolerance to a catalytic material $[27,28]$. The acidic and basic properties of the Pd catalysts studied in the present work were evaluated via temperature programmed desorption of $\mathrm{NH}_{3}$ and $\mathrm{CO}_{2}$, respectively. The temperatures of desorption peak maxima $\left(T_{\mathrm{m}}\right)$ provide information about the relative strength of acidic or basic sites, while the amount of $\mathrm{NH}_{3}$ or $\mathrm{CO}_{2}$ desorbed indicates, respectively, the relative number of acidic or basic sites on the catalyst surface. As can be seen in Fig. 6, the TPD profile varied significantly with the support type. In the fresh state, $\mathrm{Pd} / \mathrm{ZrO}_{2}$ had a large $\mathrm{NH}_{3}$ desorption peak at around $250{ }^{\circ} \mathrm{C}$ in contrast to $\mathrm{Pd} / \mathrm{SiO}_{2}$ exhibiting negligible $\mathrm{NH}_{3}$ desorption. $\mathrm{Pd} / \mathrm{ZrO}_{2}-\mathrm{SiO}_{2}$ possessed surface acidity stronger and higher than $\mathrm{Pd} / \mathrm{ZrO}_{2}$ as manifested by a larger desorption peak near $270{ }^{\circ} \mathrm{C}$. Based on the $\mathrm{NH}_{3}$-TPD results, the amount and strength of surface acidic sites were estimated to be in the order of $\mathrm{Pd} / \mathrm{ZrO}_{2}-\mathrm{SiO}_{2}>\mathrm{Pd} / \mathrm{ZrO} 2$ $>\mathrm{Pd} / \mathrm{SiO}_{2}$. This trend agrees well with the previous report that $\mathrm{TiO}_{2}-\mathrm{SiO}_{2}$ and $\mathrm{ZrO}_{2}-\mathrm{SiO}_{2}$ mixed oxides possess strong acidity [17]. Though most of the catalysts' acidity was lost with aging at $800{ }^{\circ} \mathrm{C}, \mathrm{Pd} / \mathrm{ZrO}_{2}-\mathrm{SiO}_{2}$ still had a relatively higher amount of acid sites (Table 2).

The $\mathrm{CO}_{2}$-TPD experiments showed that $\mathrm{Pd} / \mathrm{ZrO}_{2}$ possesses considerable surface basicity also as indicated by a peak at $140{ }^{\circ} \mathrm{C}$ in the fresh state (Fig. 6). On the other hand, $\mathrm{Pd} / \mathrm{SiO}_{2}$ had no interaction with $\mathrm{CO}_{2}$ confirming its generally inert nature of surface. In the case of $\mathrm{Pd} / \mathrm{ZrO}_{2}$ $\mathrm{SiO}_{2}, \mathrm{CO}_{2}$ desorption was minor with a small peak at around $130{ }^{\circ} \mathrm{C}$. It is remarkable that $\mathrm{ZrO}_{2}$ deposited on $\mathrm{SiO}_{2}$ presented a surface acido-basicity distinct from that of bulk $\mathrm{ZrO}_{2}$. Conceptually, one could expect that $\mathrm{Pd} / \mathrm{ZrO}_{2}-\mathrm{SiO}_{2}$ would present a greater sulfur tolerance than $\mathrm{Pd} / \mathrm{ZrO}_{2}$, as the former possessed only strong acidity whereas the latter possessed both strong acidity and basicity. As in the case of acidity, the surface basicity of $\mathrm{Pd} / \mathrm{ZrO}_{2}$ decreased considerably with aging at $800{ }^{\circ} \mathrm{C} . \mathrm{Pd} / \mathrm{ZrO}_{2}-\mathrm{SiO}_{2}$ presented no $\mathrm{CO}_{2}$ desorption peak after aging. The relative amounts of $\mathrm{NH}_{3}$ and $\mathrm{CO}_{2}$ desorbed are summarized in Table 2. This rather dramatic difference in $\mathrm{CO}_{2}$ uptake between $\mathrm{Pd} / \mathrm{ZrO}_{2}-\mathrm{SiO}_{2}$ and $\mathrm{Pd} / \mathrm{ZrO}_{2}$ suggests that the $\mathrm{ZrO}$ morphology can play an important role in determining surface acido-basicity of $\mathrm{ZrO}_{2}$-containing catalysts $[21,29]$.

A typical profile of the catalyst outlet sulfur concentration during the sulfation step is shown in Fig. 7 for the $\mathrm{Pd} / \mathrm{ZrO}_{2}$ and $\mathrm{Pd} / \mathrm{ZrO}_{2}-\mathrm{SiO}_{2}$ samples. During the sulfation step, there was an initial short period during which all sulfur was adsorbed, followed by a breakthrough. The total amount of sulfur adsorbed was 14.6 and $13.1 \mathrm{mmol} \cdot \mathrm{g}_{\mathrm{cat}}{ }^{-1}$ for $\mathrm{Pd} / \mathrm{ZrO}_{2}$ and $\mathrm{Pd} / \mathrm{ZrO}_{2}-\mathrm{SiO}_{2}$, 
respectively. This is consistent with the $\mathrm{CO}_{2}$-TPD experiments which indicated a higher basicity for $\mathrm{Pd} / \mathrm{ZrO}_{2}$. Consecutive temperature-programmed reduction (TPR) runs were performed with the sulfated samples of $\mathrm{Pd} / \mathrm{ZrO}_{2}$ and $\mathrm{Pd} / \mathrm{ZrO}_{2}-\mathrm{SiO}_{2}$ in order to gain further insights into their sulfur affinity. During $\mathrm{H}_{2}$-TPR, sulfur was released from both catalysts, and the resulting $\mathrm{SO}_{2}$ release profiles are shown in Fig. 8. For both catalysts, the majority of sulfur was released during the first TPR desulfation (up to $600{ }^{\circ} \mathrm{C}$ ). For $\mathrm{Pd} / \mathrm{ZrO}_{2}-\mathrm{SiO}_{2}$, the desulfation was almost complete after the second TPR desulfation (up to $700{ }^{\circ} \mathrm{C}$ ), while the release of sulfur persisted until the third TPR desulfation (up to $800{ }^{\circ} \mathrm{C}$ ) in the case of $\mathrm{Pd} / \mathrm{ZrO}_{2}$. More specifically, the total amount

of desorbed sulfur after desulfation at $800{ }^{\circ} \mathrm{C}$ was around 10 and $12 \mathrm{mmol} \cdot \mathrm{g}_{\text {cat }}{ }^{-1}$ for $\mathrm{Pd} / \mathrm{ZrO}_{2}$ and $\mathrm{Pd} / \mathrm{ZrO}_{2}-\mathrm{SiO}_{2}$ catalysts, respectively. The discrepancy between the adsorbed and desorbed sulfur was considerable for $\mathrm{Pd} / \mathrm{ZrO}_{2}$ indicating more strongly bound sulfur species remained on the surface. On the other hand, sulfur recovery was almost complete from $\mathrm{Pd} / \mathrm{ZrO}_{2}-\mathrm{SiO}_{2}$ consistent with its low surface basicity leading to more weakly bound sulfur species. This further emphasizes the importance of controlling $\mathrm{ZrO}_{2}$ morphology in determining surface acidobasicity and sulfur tolerance of $\mathrm{ZrO}_{2}$ phases.

\subsection{Catalytic Performance}

Fig. 9 represents the catalytic $\mathrm{CO}$ oxidation performance of the Pd catalysts. In addition to the temperature-conversion profiles, the $T_{50 \%}$ and $T_{90 \%}$ values (the temperatures at which $50 \%$ and 90\% conversion of $\mathrm{CO}$ were achieved, respectively) at different states were determined and summarized in Fig. 10. The fresh $\mathrm{Pd}$ catalysts supported on $\mathrm{ZrO}_{2}$-containing oxides were significantly more active than the fresh $\mathrm{Pd} / \mathrm{SiO}_{2}$. For example, the $T_{90 \%}$ for the fresh $\mathrm{Pd} / \mathrm{ZrO}_{2}$ and $\mathrm{Pd} / \mathrm{ZrO}_{2}-\mathrm{SiO}_{2}$ was 183 and $225{ }^{\circ} \mathrm{C}$, respectively, compared to $276{ }^{\circ} \mathrm{C}$ for the fresh $\mathrm{Pd} / \mathrm{SiO}_{2}$. Their excellent $\mathrm{CO}$ oxidation activity can be attributed to high $\mathrm{Pd}$ dispersion due to good metal-support interaction which could have also affected the electronic state of finely dispersed Pd atoms. The oxidation activity of the $\mathrm{Pd} / \mathrm{SiO}_{2}$ catalysts was significantly decreased after the hydrothermal aging at 800 and $900{ }^{\circ} \mathrm{C}$, while the two $\mathrm{ZrO}_{2}$-containing catalysts maintained relatively good performance. The stability of $\mathrm{Pd} / \mathrm{ZrO}_{2}$ was especially remarkable with an almost unchanged $\mathrm{CO}$ oxidation activity even after $900{ }^{\circ} \mathrm{C}$ aging. The fact that both activity loss (Figs. 9,10) and Pd agglomeration (Figs. 2-4) were significant only with $\mathrm{Pd} / \mathrm{SiO}_{2}$ further highlights the importance of Pd dispersion for oxidation activity. 
Fig. 11 presents the catalytic $\mathrm{C}_{3} \mathrm{H}_{6}$ oxidation performance of the Pd catalysts in fresh, 800 and $900{ }^{\circ} \mathrm{C}$ aged states. The $T_{50 \%}$ and $T_{90 \%}$ values for the $\mathrm{C}_{3} \mathrm{H}_{6}$ oxidation activity of all the catalysts are listed in Fig. 12. For all catalysts studied, $\mathrm{C}_{3} \mathrm{H}_{6}$ oxidation light-off occurred at higher temperatures than $\mathrm{CO}$ light-off, which is generally observed over other types of catalysts and explained by the fact that $\mathrm{C}_{3} \mathrm{H}_{6}$ oxidation occurs after $\mathrm{CO}$ molecules have been desorbed from the active sites [11,30,31]. Again, $\mathrm{Pd} / \mathrm{ZrO}_{2}$ and $\mathrm{Pd} / \mathrm{ZrO}_{2}-\mathrm{SiO}_{2}$ catalysts exhibited superior $\mathrm{C}_{3} \mathrm{H}_{6}$ oxidation activity with a $T_{90 \%}$ of 192 and $227{ }^{\circ} \mathrm{C}$, respectively. Catalytic performance in $\mathrm{C}_{3} \mathrm{H}_{6}$ oxidation degraded with hydrothermal aging at 800 and $900{ }^{\circ} \mathrm{C}$, but the $\mathrm{ZrO}_{2}$-containing catalysts still maintained a good portion of the initial activity compared to $\mathrm{Pd} / \mathrm{SiO}_{2}$. The desulfation properties were studied under rich conditions in this work, and the results can be relevant to certain diesel applications such as the ones employing lean $\mathrm{NO}_{\mathrm{x}}$ traps for $\mathrm{NO}_{\mathrm{x}}$ control; as intrinsically cyclic lean/rich operation of lean $\mathrm{NO}_{\mathrm{x}}$ traps would allow creating rich exhaust conditions necessary for DOC desulfation placed upstream. However, in lean aftertreament systems equipped with alternative $\mathrm{NO}_{\mathrm{x}}$ control devices for example selective catalytic reduction catalysts, the engine exhausts are expected to be continuously lean. Therefore, further desulfation studies are needed to confirm that $\mathrm{ZrO}_{2}-\mathrm{SiO}_{2}$ maintains sulfur-tolerance advantage over $\mathrm{ZrO}_{2}$ in lean desulfation conditions. Our preliminary lean desulfation data reported in Fig. $\mathrm{S} 1$ indicate that $\mathrm{SO}_{2}$ can be removed from $\mathrm{Pd} / \mathrm{ZrO}_{2}-\mathrm{SiO}_{2}$ at significantly lower temperatures than from $\mathrm{Pd} / \mathrm{ZrO}_{2}$.

After sulfation, the $\mathrm{CO}$ and $\mathrm{C}_{3} \mathrm{H}_{6}$ oxidation activity of both catalysts notably decreased and higher temperatures were required for light-off (Figs. 13-16). As an example, the CO oxidation $\mathrm{T}_{50 \%}$ over $\mathrm{Pd} / \mathrm{ZrO}_{2}$ and $\mathrm{Pd} / \mathrm{ZrO}_{2}-\mathrm{SiO}_{2}$ increased to 226 and $232{ }^{\circ} \mathrm{C}$, respectively (Figs. 13, 15). The performance degradation was greater for the $\mathrm{Pd} / \mathrm{ZrO}_{2}$ catalyst, which can be explained by the larger amount of sulfur being adsorbed on this catalyst (Fig. 7). After desulfation at $600{ }^{\circ} \mathrm{C}$, $\mathrm{Pd} / \mathrm{ZrO}_{2}-\mathrm{SiO}_{2}$ regained its initial activity, whereas $100 \%$ of the initial activity could not be fully recovered for the $\mathrm{Pd} / \mathrm{ZrO}_{2}$ catalyst even after desulfation at $800{ }^{\circ} \mathrm{C}$. This is likely due to residual sulfur species on the surface as described above, but the $\mathrm{T}_{50 \%}$ and $\mathrm{T}_{90 \%}$ are only $5-10^{\circ} \mathrm{C}$ higher for both $\mathrm{CO}$ and $\mathrm{C}_{3} \mathrm{H}_{6}$ (Figs.15,16).

In summary, the performance data are in good agreement with the characterization results obtained with XRD, TEM, and SEM, which highlight the ability of $\mathrm{ZrO}_{2}$ to achieve a superior dispersion and stability of $\mathrm{Pd}$ particles leading to much better low-temperature $\mathrm{CO}$ and $\mathrm{C}_{3} \mathrm{H}_{6}$ 
oxidation activity than $\mathrm{Pd} / \mathrm{SiO}_{2}$. In the case of the $\mathrm{Pd} / \mathrm{ZrO}_{2}-\mathrm{SiO}_{2}$ catalyst, as $\mathrm{Pd}$ was deposited on both $\mathrm{ZrO}_{2}$ and $\mathrm{SiO}_{2}$ surfaces, the oxidation performance was found somehow between those of $\mathrm{Pd} / \mathrm{ZrO}_{2}$ and $\mathrm{Pd} / \mathrm{SiO}_{2}$ but closer to $\mathrm{Pd} / \mathrm{ZrO}_{2}$. However, the unique $\mathrm{ZrO}_{2}$ morphology of $\mathrm{Pd} / \mathrm{ZrO}_{2^{-}}$ $\mathrm{SiO}_{2}$ conferred a better sulfur tolerance to this catalyst than $\mathrm{Pd} / \mathrm{ZrO}_{2}$. More complete $\mathrm{ZrO}{ }_{2}$ coverage of $\mathrm{SiO}_{2}$ supports or selective deposition of $\mathrm{Pd}$ precursors onto $\mathrm{ZrO}_{2}$ surfaces thus appear to be important design considerations to maximize Pd dispersion and thermal stability potentially leading to a catalyst which outperforms $\mathrm{Pd} / \mathrm{ZrO}_{2}$.

\section{Conclusions}

We investigated the impact of $\mathrm{ZrO}_{2}$ on the catalytic performance of Pd-based oxidation catalysts in simulated lean automotive exhaust conditions. Key findings in the present study were:

- $\mathrm{ZrO}_{2}$ is an excellent support for Pd catalysts leading to high dispersion, hydrothermal stability, and low-temperature $\mathrm{CO}$ and $\mathrm{C}_{3} \mathrm{H}_{6}$ oxidation activity;

- $\mathrm{ZrO}_{2}$ incorporation on $\mathrm{SiO}_{2}$ via sol-gel method before $\mathrm{Pd}$ impregnation led to enhanced dispersion and hydrothermal stability of $\mathrm{Pd}$ due to stronger interaction between Pd and supports;

- Likely due to its unique morphology, the $\mathrm{ZrO}_{2}$ phases incorporated on $\mathrm{SiO}_{2}$ surface presented strong acidity but negligible strong basicity on the surface, whereas bulk $\mathrm{ZrO}_{2}$ had both strong acidity and basicity;

- Lack of strong basicity imparted an excellent sulfur tolerance to $\mathrm{Pd} / \mathrm{ZrO}_{2}-\mathrm{SiO}_{2}$;

- Incomplete coverage of $\mathrm{SiO}_{2}$ surface by $\mathrm{ZrO}_{2}$ led to an overall lower accessible $\mathrm{ZrO}_{2}$ surface area and $\mathrm{Pd}$ deposition on both $\mathrm{ZrO}_{2}$ and $\mathrm{SiO}_{2}$ surfaces limiting the full potential of $\mathrm{Pd} / \mathrm{ZrO}_{2}-\mathrm{SiO}_{2}$ catalyst concept in the samples evaluated here;

- Further research is necessary to further our understanding of the structure and chemistry of $\mathrm{ZrO}_{2}$ layer on $\mathrm{SiO}_{2}$ and to find strategies to obtain more complete $\mathrm{ZrO}_{2}$ coverage of $\mathrm{SiO}_{2}$ and selective $\mathrm{Pd}$ deposition on $\mathrm{ZrO}_{2}$ surfaces.

\section{Acknowledgments}


This research was sponsored by the U.S. Department of Energy, Office of Energy Efficiency and Renewable Energy, Vehicle Technologies Office (Program Managers: Gurpreet Singh, Ken Howden and Leo Breton) and French National Centre for Scientific Research. A portion of this research including the microscopy experiments was conducted at ORNL's Center for Nanophase Materials Sciences, which is a DOE Office of Science User Facility. We thank Saint-Gobain for providing the zirconia sample.

\section{References}

[1] A. Russell, W.S. Epling, Catal. Rev. Sci. Eng. 53(2011) 337.

[2] T.V. Johnson, SAE Int. J. Fuels Lubr. 2 (2009) 1.

[3] A. Manigrasso, N. Fouchal, P. Darcy, P.D. Costa, Catal. Today 191 (2012) 52.

[4] M. Haruta, J. New. Mat. Electrochem. Systems 7 (2004) 163.

[5] L. Li, Q. Chen, Q. Zhang, J. Shi, Y. Li, W. Zhao, J. Shi, Catal. Commun. 26 (2012) 15.

[6] S. Li, H. Zhu, Z. Qin, G. Wang, Y. Zhang, Z. Wu, Z. Li, G. Chen, W. Dong, Z. Wu, L.

Zheng, J. Zhang, T. Hu, J. Wang, Appl. Catal. B: Environ. 144 (2014) 498.

[7] X. Zhang, Z. Qu, F. Yu, Y. Wang, J. Catal. 297 (2013) 264.

[8] S. Golunski, Platinum Metals Rev. 51 (2007) 162.

[9] J.A. Moulijn, A.E. Diepen, F. Kapteijn, Appl. Catal. A: Gen 212 (2001) 3.

[10] H.Shinjoh, Catal. Surv. Asia 13 (2009) 184.

[11] F.C. Galisteo, R. Mariscal, M.L. Granados, M.D.Z.A. Poves, J.L.G. Fierro, V. Kröger, R.L. Keiski, Appl. Catal. B: Environ. 72 (2007) 272.

[12] L. Liu, F. Zhou, L. Wang, Z. Qi, F. Shi, Y. Deng, J. Catal. 274 (2010) 1.

[13] A.Tomita, K. Shimizu, K. Kato, Y. Tai, Catal. Commun. 17 (2012) 194.

[14] Y. Shen, G. Lu, Y. Guo, Y. Wang, Y. Guo, L. Wang, X. Zhen, Catal. Commun. 18 (2012) 26.

[15] M. Cargnello, J.J.D. Jaén, J.C.H. Garrido, K. Bakhmutsky, T. Montini, J.J.G. Gámez, R.J. Gorte, P. Fornasiero, Science 337 (2012) 713.

[16] X. Guo, Q. Fu, Y. Ning, M. Wei, M. Li, S. Zhang, Z. Jiang, X. Bao, J. Am. Chem. Soc. 134 (2012) 12350.

[17] M.-Y. Kim, J.-S. Choi, T. Toops, E.-S. Jeong, S.-W. Han, V. Schwartz, J. Chen, Catalysts 
3 (2013) 88.

[18] M.-Y. Kim, S.M. Park, G. Seo, K.-S. Song, Catal. Lett. 138 (2010) 205.

[19] B. Buszewski, S. Bocian, G. Rychlicki, M. Matyska, J. Pesek, J. Chromatography A 1232 (2012) 43.

[20] C. Thomas, J. Phys. Chem. C 115 (2011) 2253.

[21] H.Y. Law, J. Blanchard, X. Carrier, C. Thomas, J. Phys. Chem. C 114 (2010) 9731.

[22] T.J. Toops, B.G. Bunting, K. Nguyen, A. Gopinath, Catal. Today 123 (2007) 285.

[23] T.J. Toops, N.A. Ottinger, C. Liang, J.A. Pihl, E.A. Payzant, Catal. Today 160 (2011) 131.

[24] Z.A. Alothman, Materials 5 (2012) 2874.

[25] S. Jayakumara, P.V. Ananthapadmanabhan, K. Perumal, T.K. Thiyagarajan, S.C. Mishra, L.T. Sue, A.I.Y. Toke, J. Guo, Mater. Sci. Eng. B 176 (2011) 894.

[26] T. Bonnotte, C. Sayag, R.P. Doherty, J-M. Krafft, C. Méthivier, F. Ser, M. Sicard, C. Thomas, J. Phys. Chem. C 118 (2014) 7386.

[27] J. Oi-Uchisawa, A. Obuchi, R. Enomoto, S. Liu, T. Nanba, S. Kushiyama, Appl. Catal. B 26 (2000) 17.

[28] S. Matsumoto, Y. Ikeda, H. Suzuki, M. Ogai, N. Miyoshi, Appl. Catal. B 25 (2000) 115.

[29] K. Pokrovski, K. Taek Jung, A.T. Bell, Langmuir 17 (2001) 4297.

[30] C. Larese, M.L. Granados, F.C. Galisteo, R. Mariscal, J.L.G. Fierro, Appl. Catal. B: Environ. 62 (2006) 132.

[31] J.M.A. Harmsen, J.H.B.J. Hoebink, J.C. Shouten, Ind. Eng. Chem. Res. 39 (2000) 599. 
Table 1

Chemical composition and physical properties of Pd catalysts

\begin{tabular}{|c|c|c|c|c|c|c|}
\hline \multirow[t]{2}{*}{ Samples } & \multicolumn{2}{|c|}{ Composition $(\mathrm{wt} \%)^{a}$} & \multirow{2}{*}{$\begin{array}{l}\text { Surface area } \\
\qquad\left(\mathrm{m}^{2} / \mathrm{g}\right)^{b}\end{array}$} & \multirow{2}{*}{$\begin{array}{l}\text { Pore volume } \\
\qquad\left(\mathrm{cm}^{3} / \mathrm{g}\right)^{b}\end{array}$} & \multirow{2}{*}{$\begin{array}{c}\text { Average pore } \\
\text { size }(\mathrm{nm})^{b}\end{array}$} & \multirow{2}{*}{$\begin{array}{c}\text { Pd particle size } \\
(\mathrm{nm})^{c}\end{array}$} \\
\hline & $\mathrm{Pd}$ & $\mathrm{Zr}$ & & & & \\
\hline Fresh $\mathrm{Pd} / \mathrm{ZrO}_{2}$ & 1.13 & n.d. & 93 & 0.278 & 9.8 & n.d. \\
\hline Aged $\mathrm{Pd} / \mathrm{ZrO}_{2}{ }^{d}$ & n.d. & n.d. & 24 & 0.196 & 32.5 & $1.1 \pm 0.3$ \\
\hline Fresh $\mathrm{Pd} / \mathrm{SiO}_{2}$ & 1.13 & n.d. & 447 & 0.903 & 7.1 & $2.4 \pm 1.1$ \\
\hline Aged $\mathrm{Pd} / \mathrm{SiO}_{2}{ }^{d}$ & n.d. & n.d. & 301 & 0.562 & 7.0 & $4.1 \pm 1.8$ \\
\hline Fresh $\mathrm{Pd} / \mathrm{ZrO}_{2}-\mathrm{SiO}_{2}$ & 1.14 & 12.1 & 404 & 0.680 & 6.3 & $3.6 \pm 2.0$ \\
\hline Aged $\mathrm{Pd} / \mathrm{ZrO}_{2}-\mathrm{SiO}_{2}{ }^{d}$ & n.d. & n.d. & 325 & 0.578 & 6.7 & $1.9 \pm 1.0$ \\
\hline
\end{tabular}

${ }^{a}$ measured by ICP-AES.

${ }^{b}$ measured at liquid nitrogen temperature.

${ }^{c}$ calculated from TEM images; number of Pd particles measured: 34-184.

${ }^{d}$ aged at $800{ }^{\circ} \mathrm{C}$ for $16 \mathrm{~h}$. 
Table 2

Accessible $\mathrm{ZrO}_{2}$ surface area, $\mathrm{ZrO}_{2}$ particle size, and surface acid-base properties of Pd catalysts

\begin{tabular}{lllccccc}
\hline Samples & $\begin{array}{c}\mathrm{NO}_{\mathrm{x}} \text { uptake } \\
(\mu \mathrm{mol} / \mathrm{g})\end{array}$ & $\begin{array}{c}\mathrm{ZrO}_{2} \text { surface area } \\
\left(\mathrm{m}^{2} / \mathrm{g}\right)\end{array}$ & $\begin{array}{c}\mathrm{ZrO}_{2} \text { particle size }(\mathrm{nm}) \\
\left(\mathrm{m}^{2} / \mathrm{g}_{\mathrm{ZrO} 2}\right)\end{array}$ & $\begin{array}{c}\mathrm{NO}_{\mathrm{x}} \mathrm{TPD} \\
\mathrm{NH}_{3} \text { uptake }\end{array}$ & $\mathrm{CRD}$ & $\begin{array}{c}\mathrm{CO}_{2} \text { uptake } \\
(\mu \mathrm{mol} / \mathrm{g})\end{array}$ & $(\mu \mathrm{mol} / \mathrm{g})$ \\
\hline Fresh $\mathrm{Pd} / \mathrm{ZrO}_{2}$ & 495 & 83 & 84 & 12 & 11 & 111 & 122 \\
Aged $\mathrm{Pd} / \mathrm{ZrO}_{2}{ }^{b}$ & 148 & 25 & 25 & 41 & 27 & 5 & 10 \\
Fresh $\mathrm{Pd} / \mathrm{SiO}_{2}$ & 0 & 0 & 0 & - & - & 1 & 0 \\
Aged $\mathrm{Pd} / \mathrm{SiO}_{2}{ }^{b}$ & 0 & 0 & 0 & - & - & 0 & 0 \\
Fresh $\mathrm{Pd} / \mathrm{ZrO}_{2}-\mathrm{SiO}_{2}$ & 327 & 54 & 332 & 3 & n.d. & 155 & 2 \\
Aged $\mathrm{Pd} / \mathrm{ZrO}_{2}-\mathrm{SiO}_{2}{ }^{b}$ & 50 & 8 & 50 & 21 & n.d. & 18 & 1 \\
\hline
\end{tabular}

${ }^{a}$ calculated from $\mathrm{NO}_{\mathrm{x}}$ TPD experiments.

${ }^{b}$ aged at $800{ }^{\circ} \mathrm{C}$ for $16 \mathrm{~h}$. 


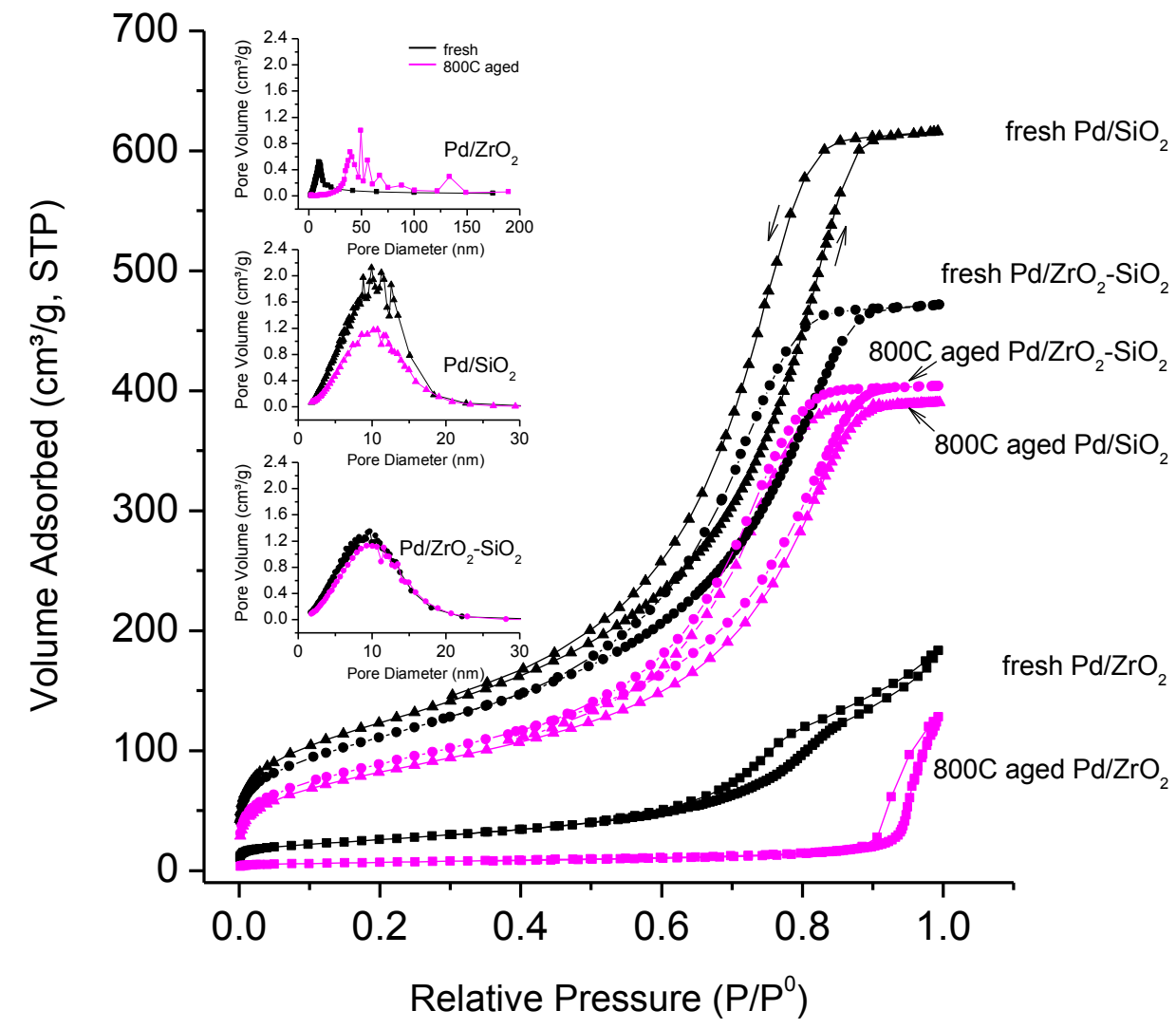

Fig. 1. Nitrogen adsorption and desorption isotherms of $\mathrm{Pd} / \mathrm{ZrO} 2, \mathrm{Pd} / \mathrm{SiO}{ }_{2}$, and $\mathrm{Pd} / \mathrm{ZrO}_{2}-\mathrm{SiO}_{2}$ in fresh and hydrothermally aged states. The inset figures present $\mathrm{BJH}$ pore size distributions for $\mathrm{Pd}$ catalysts as determined from the nitrogen adsorption curves. 


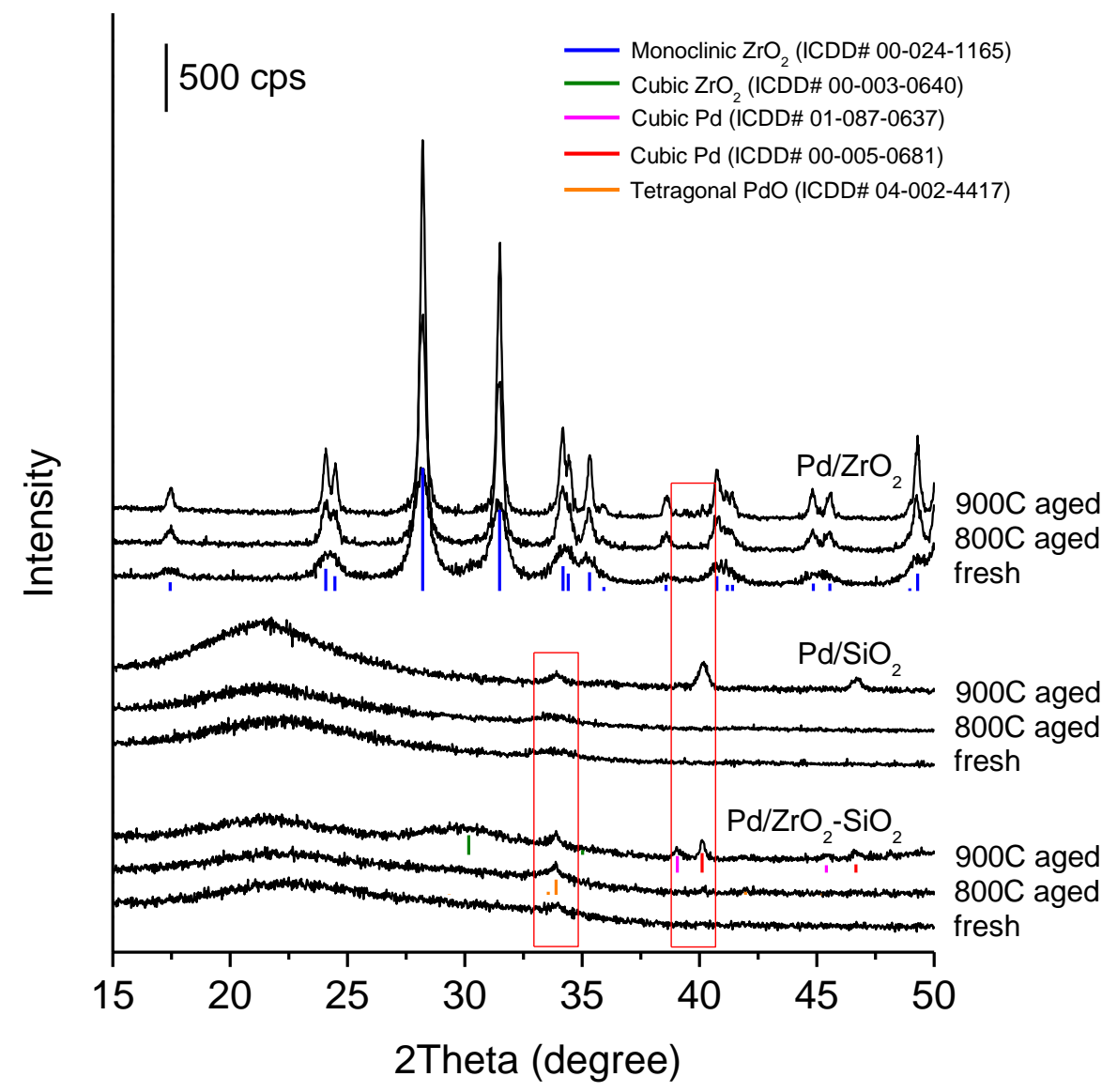

Fig. 2. $\mathrm{XRD}$ patterns of $\mathrm{Pd} / \mathrm{ZrO}_{2}, \mathrm{Pd} / \mathrm{SiO}_{2}$, and $\mathrm{Pd} / \mathrm{ZrO}_{2}-\mathrm{SiO}_{2}$ in fresh and hydrothermally aged states. 

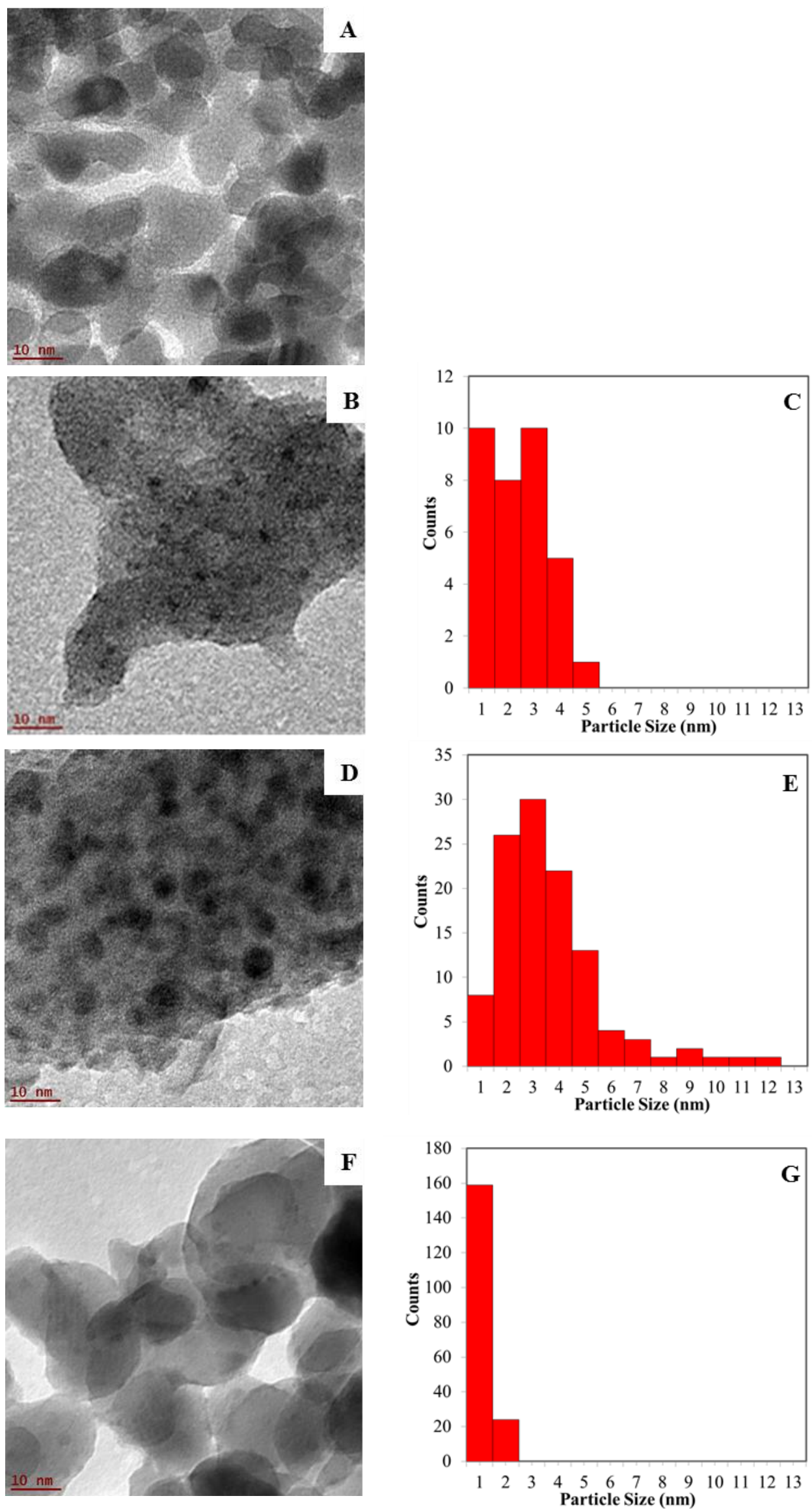

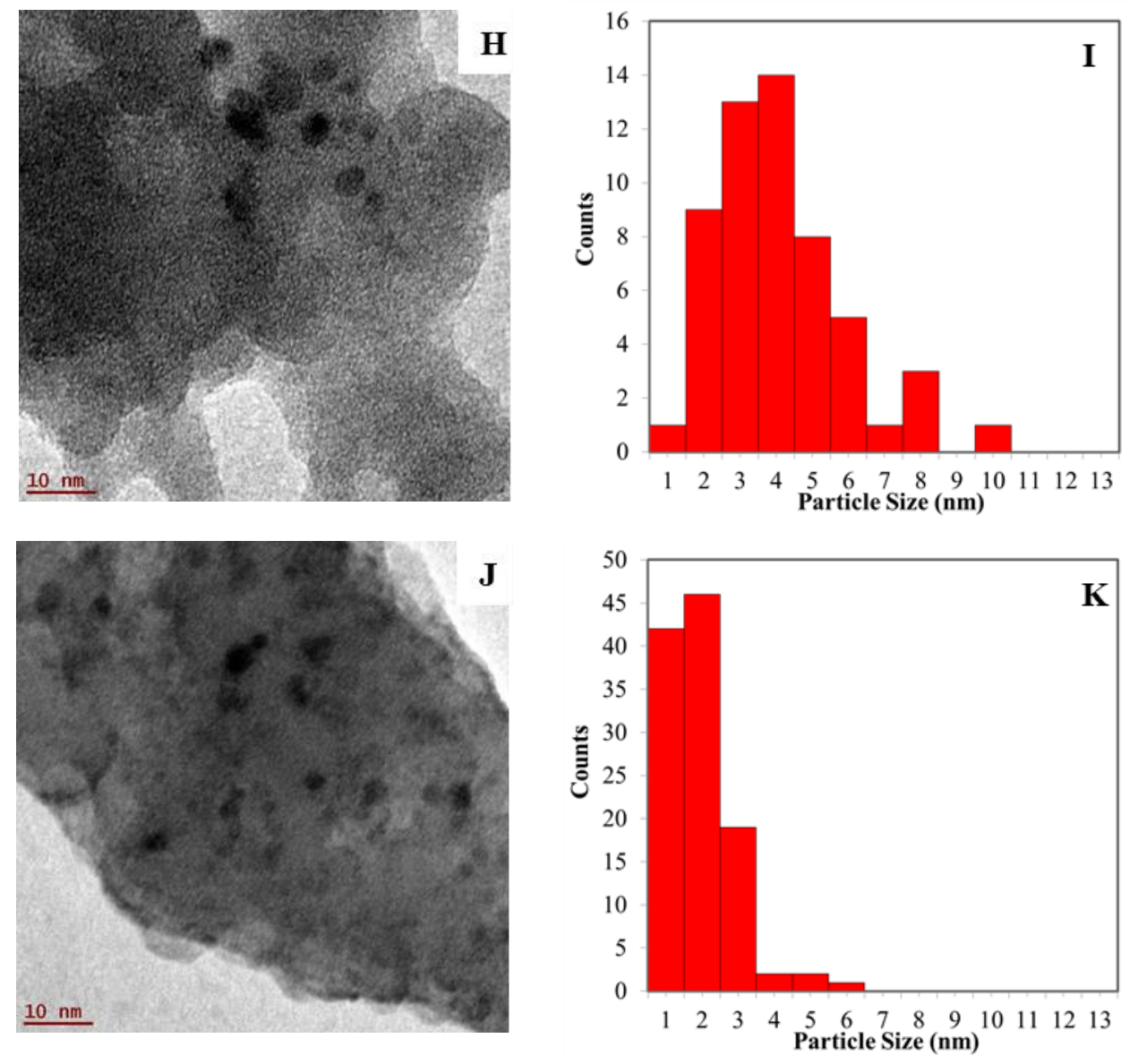

Fig. 3. TEM micrographs and particle size distributions of fresh $\mathrm{Pd} / \mathrm{ZrO}_{2}(\mathrm{~A})$, fresh $\mathrm{Pd} / \mathrm{SiO}_{2},(\mathrm{~B}$, C), fresh $\mathrm{Pd} / \mathrm{ZrO}_{2}-\mathrm{SiO}_{2}(\mathrm{D}, \mathrm{E}), 800{ }^{\circ} \mathrm{C}$-aged $\mathrm{Pd} / \mathrm{ZrO}_{2}(\mathrm{~F}, \mathrm{G}), 800{ }^{\circ} \mathrm{C}$-aged $\mathrm{Pd} / \mathrm{SiO}_{2}(\mathrm{H}, \mathrm{I})$ and 800 ${ }^{\circ} \mathrm{C}$-aged $\mathrm{Pd} / \mathrm{ZrO}_{2}-\mathrm{SiO}_{2}(\mathrm{~J}, \mathrm{~K})$. 

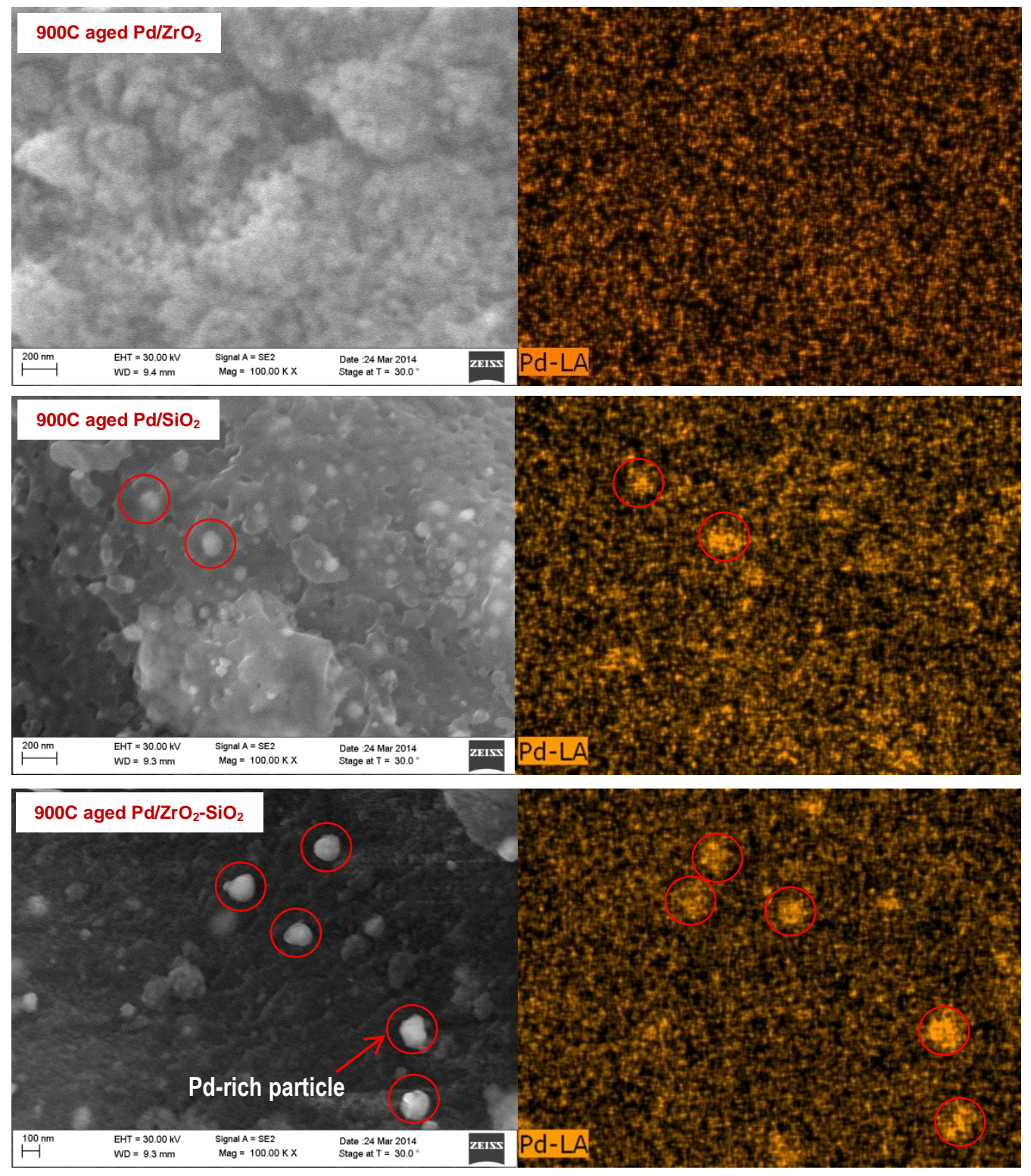

Fig. 4. SEM images (left) and EDX $\mathrm{Pd}$ maps (right) of $\mathrm{Pd} / \mathrm{ZrO}_{2}, \mathrm{Pd} / \mathrm{SiO}_{2}$, and $\mathrm{Pd} / \mathrm{ZrO}_{2}-\mathrm{SiO}_{2}$ in hydrothermally aged state; a few representative Pd-rich particles are marked with circles in the images. 

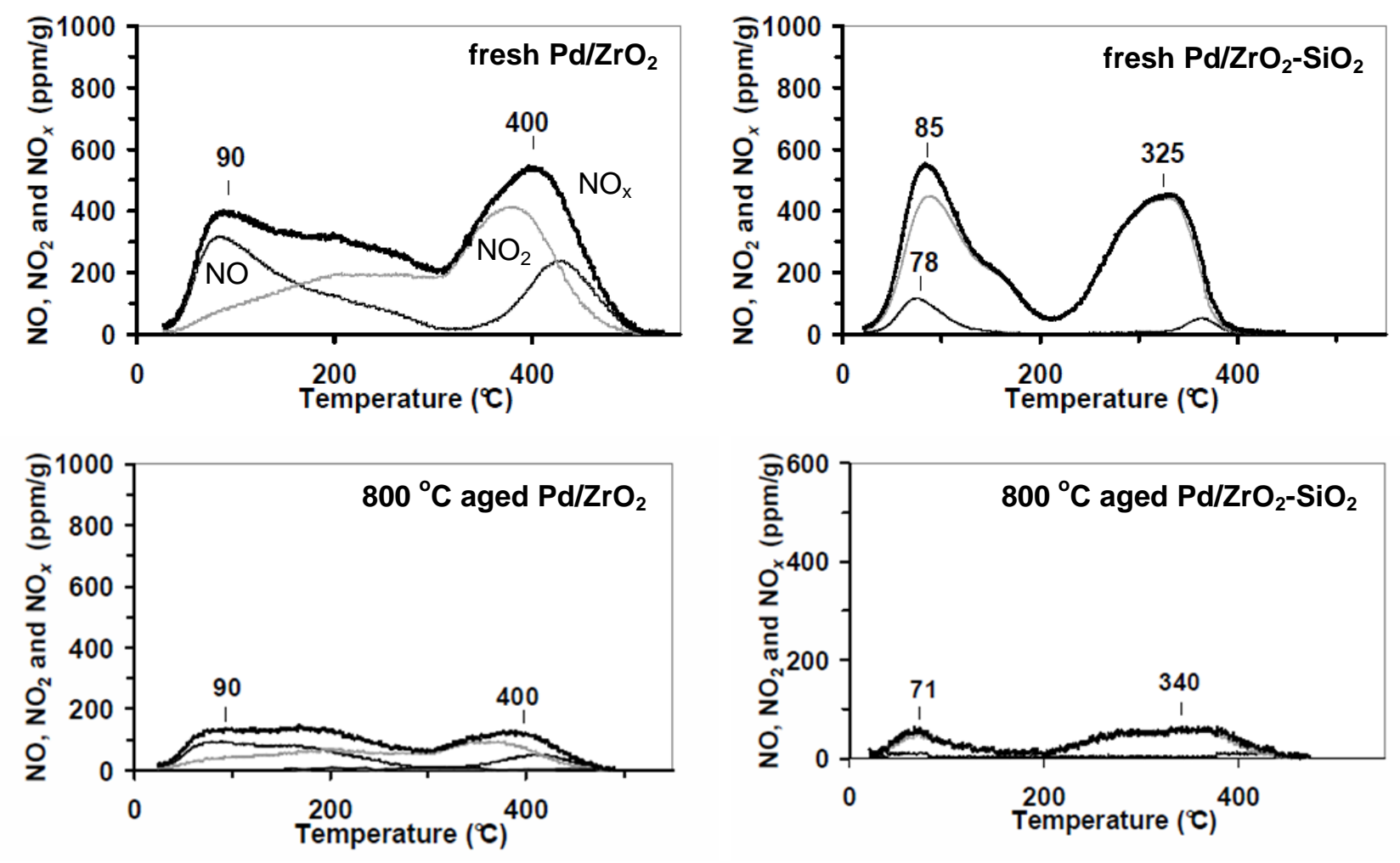

Fig. 5. $\mathrm{NO}_{\mathrm{x}}-\mathrm{TPD}$ profiles of $\mathrm{Pd} / \mathrm{ZrO}_{2}$ and $\mathrm{Pd} / \mathrm{ZrO}_{2}-\mathrm{SiO}_{2}$ in fresh and hydrothermally aged states. 

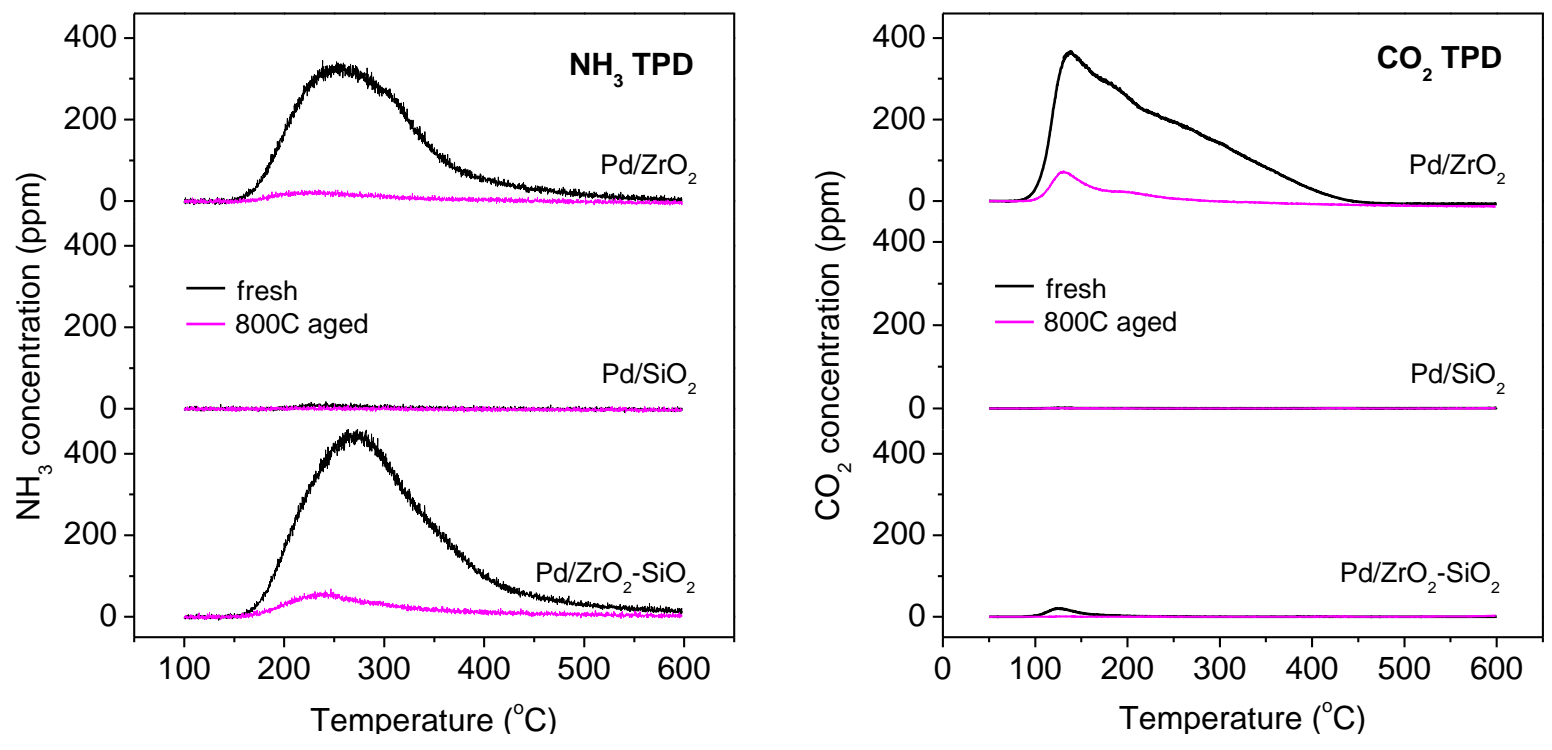

Fig. 6. $\mathrm{NH}_{3}$ and $\mathrm{CO}_{2}$ TPD profiles of $\mathrm{Pd} / \mathrm{ZrO}_{2}, \mathrm{Pd} / \mathrm{SiO}_{2}$, and $\mathrm{Pd} / \mathrm{ZrO}_{2}-\mathrm{SiO}_{2}$ in fresh and hydrothermally aged states. 


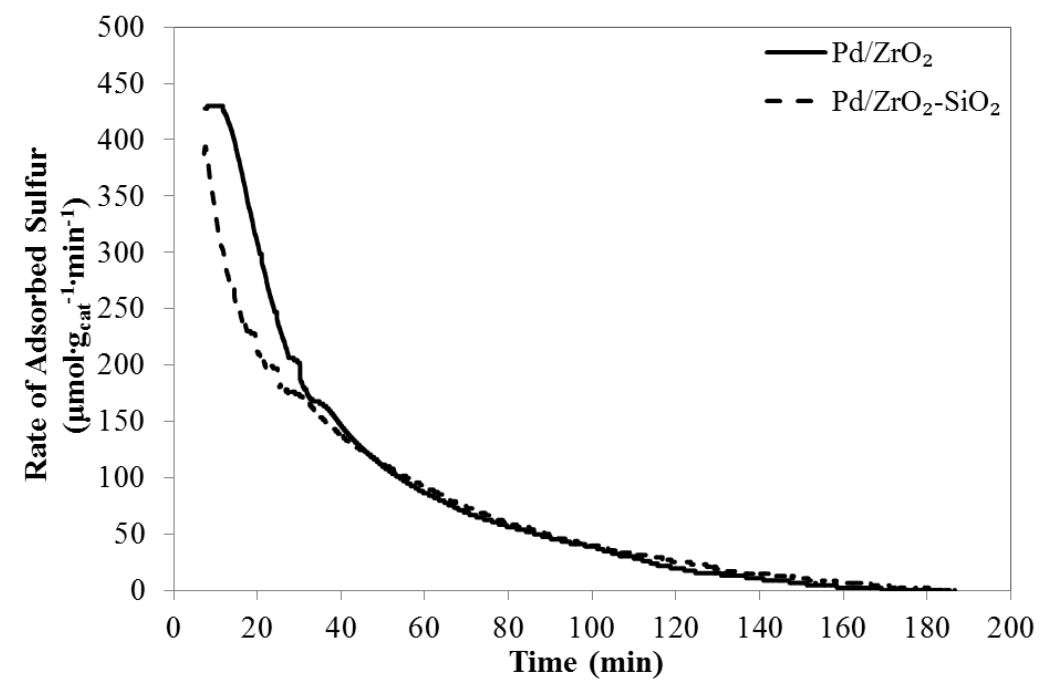

Fig. 7. Rate of $\mathrm{SO}_{2}$ adsorption measured during the catalyst sulfation $\left(50 \mathrm{ppm} \mathrm{SO}_{2}, 5 \% \mathrm{H}_{2} \mathrm{O}, 4 \%\right.$ $\mathrm{O}_{2}$, balance $\mathrm{Ar}$ ). 

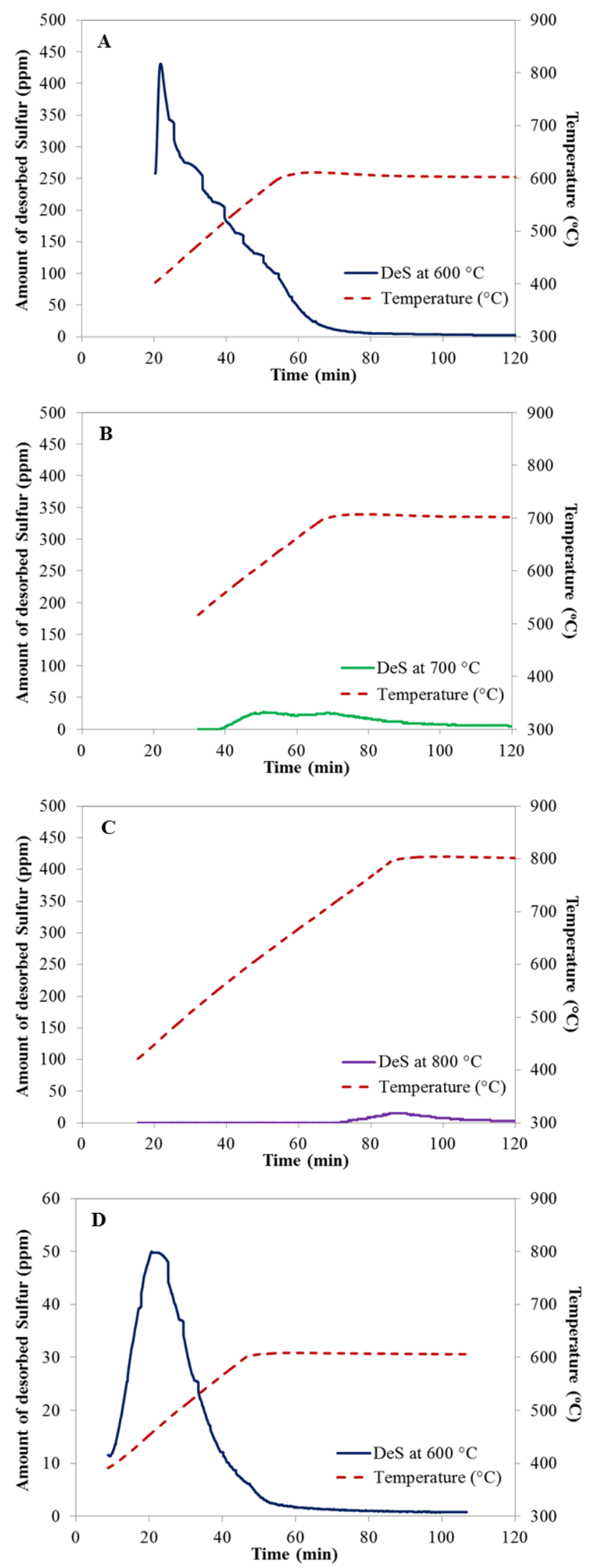

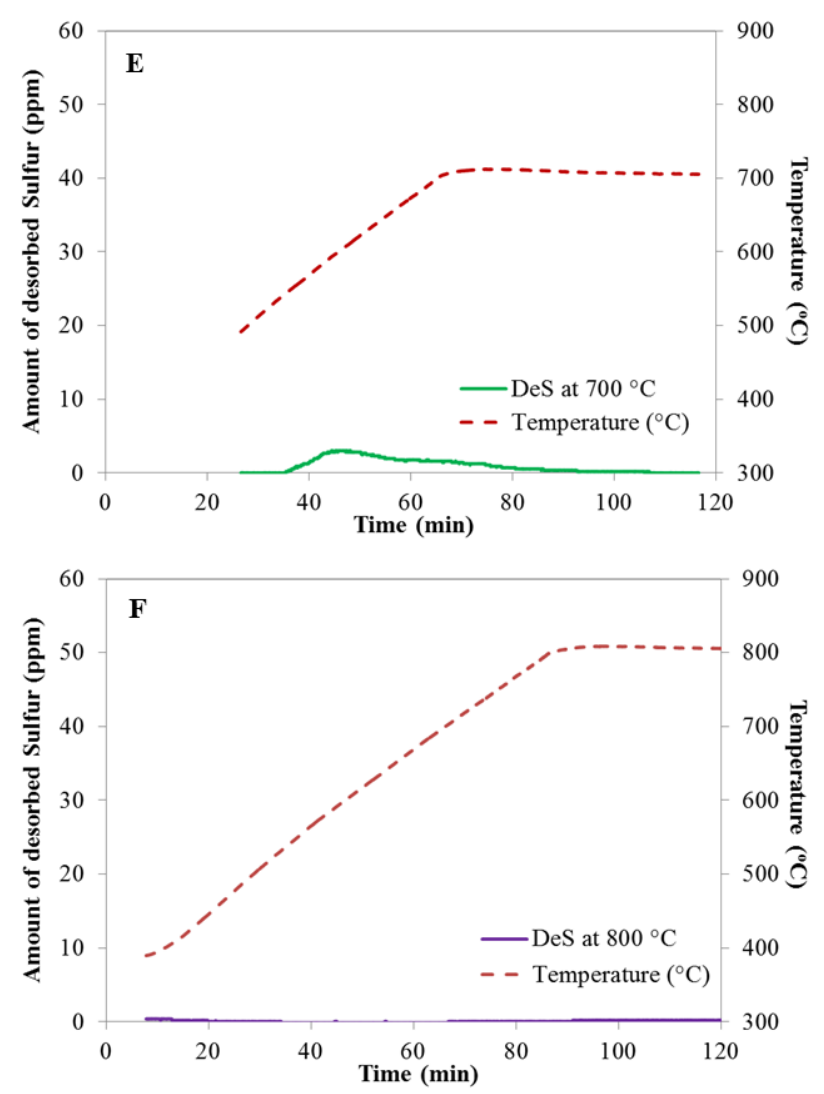

Fig. 8. Sulfur release profiles obtained during consecutive temperature-programmed reduction desulfation runs $\left(1 \% \mathrm{H}_{2}\right.$ and $5 \% \mathrm{H}_{2} \mathrm{O}$ in $\mathrm{Ar}$; up to 600,700 and $\left.800{ }^{\circ} \mathrm{C}\right)$ for $\mathrm{Pd} / \mathrm{ZrO}_{2}(\mathrm{~A}-\mathrm{C})$ and $\mathrm{Pd} / \mathrm{ZrO}_{2}-\mathrm{SiO}_{2}$ (D-F) catalysts. 


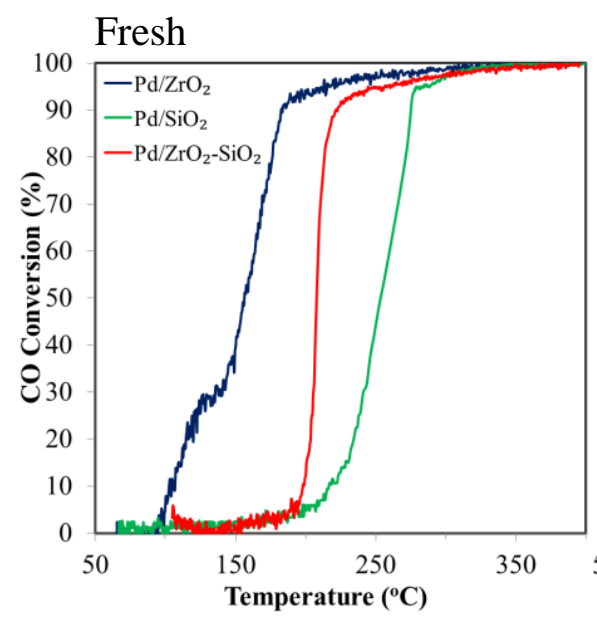

$800^{\circ} \mathrm{C}$ aged

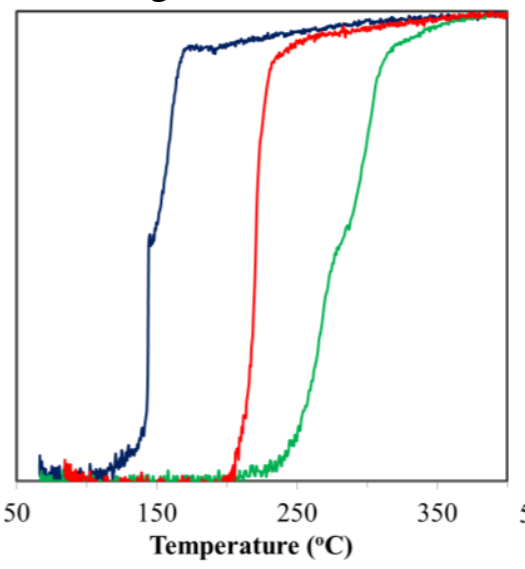

$900^{\circ} \mathrm{C}$ aged

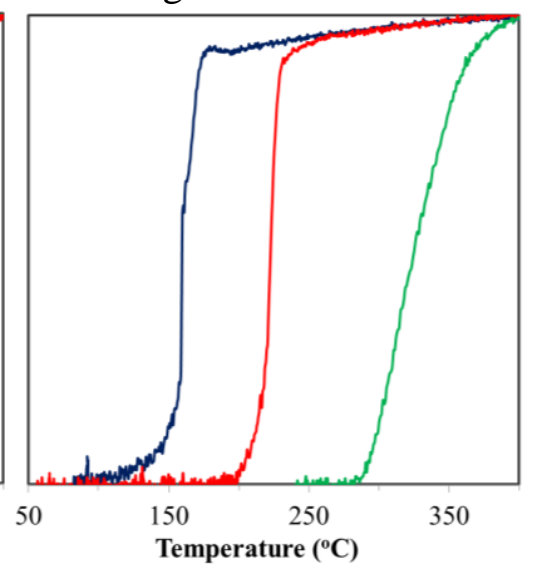

Fig. 9. Catalytic performance of $\mathrm{Pd} / \mathrm{ZrO}_{2}, \mathrm{Pd} / \mathrm{SiO}_{2}$, and $\mathrm{Pd} / \mathrm{ZrO}_{2}-\mathrm{SiO}_{2}$ in $\mathrm{CO}$ oxidation at a total flow rate of $200 \mathrm{ml} / \mathrm{min}\left(4000 \mathrm{ppm} \mathrm{CO} / 1000 \mathrm{ppm} \mathrm{C}_{3} \mathrm{H}_{6} / 500 \mathrm{ppm} \mathrm{NO}+10 \% \mathrm{O}_{2}+5 \% \mathrm{H}_{2} \mathrm{O}+\mathrm{Ar}\right.$ balance) over fresh and hydrothermally-aged catalysts. 

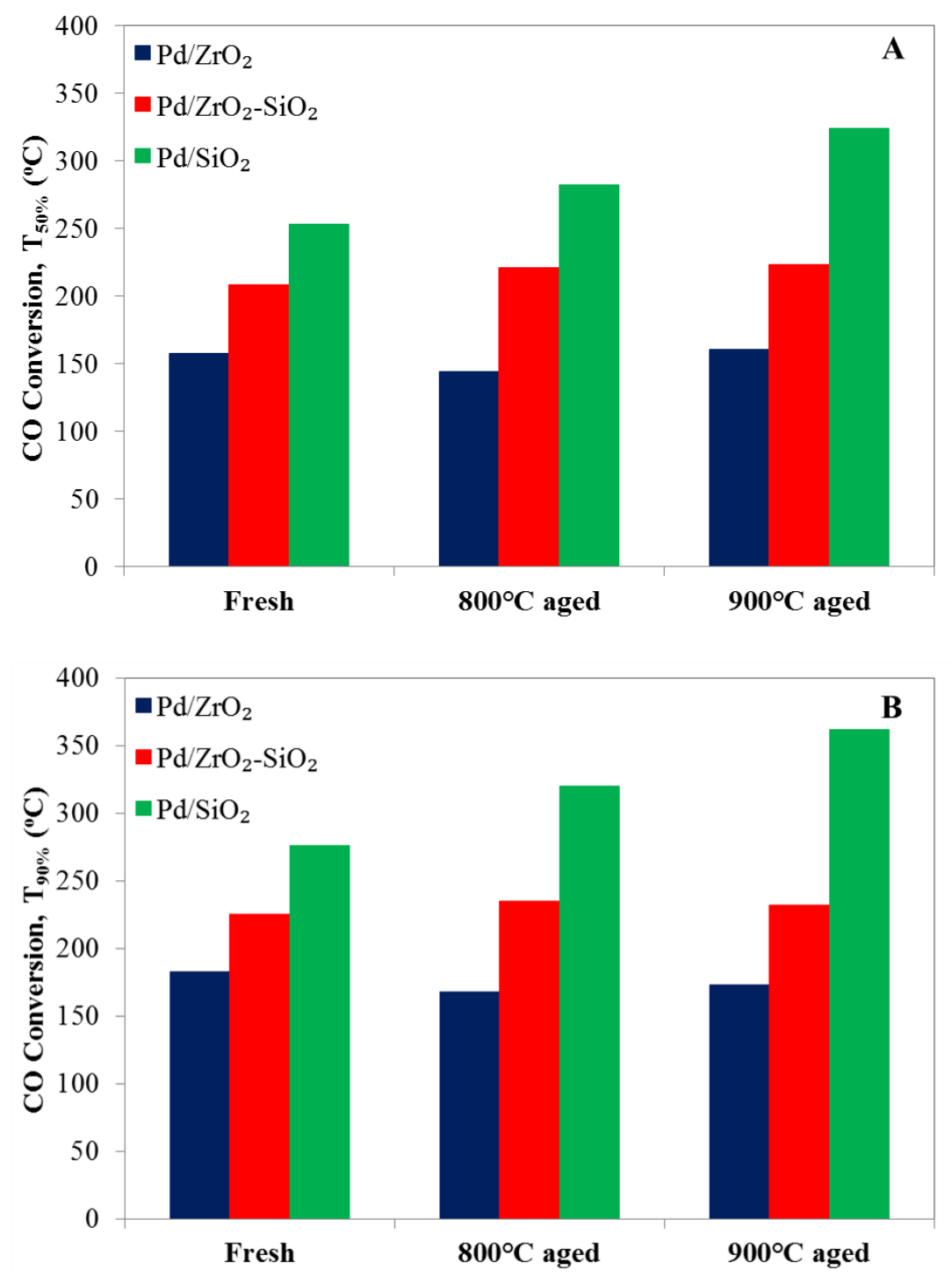

Fig. 10. Comparison of $\mathrm{CO}$ conversion $T_{50 \%}(\mathrm{~A})$ and $T_{90 \%}(\mathrm{~B})$ for $\mathrm{Pd} / \mathrm{ZrO}_{2}, \mathrm{Pd} / \mathrm{SiO}_{2}$ and $\mathrm{Pd} / \mathrm{ZrO}_{2^{-}}$ $\mathrm{SiO}_{2}$ at a total flow rate of $200 \mathrm{ml} / \mathrm{min}\left(4000 \mathrm{ppm} \mathrm{CO}+1000 \mathrm{ppm} \mathrm{C}_{3} \mathrm{H}_{6}+500 \mathrm{ppm} \mathrm{NO}+10 \% \mathrm{O}_{2}+\right.$ $5 \% \mathrm{H}_{2} \mathrm{O}+$ Ar balance) over fresh and hydrothermally aged catalysts.

Fresh 

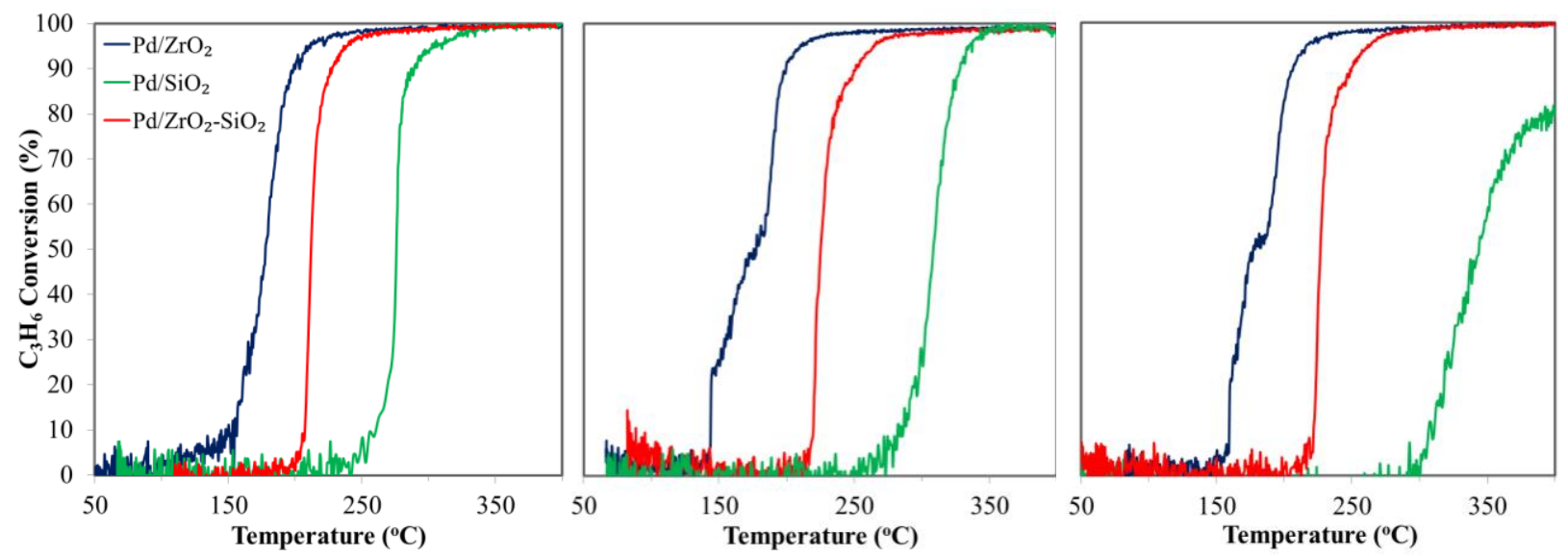

Fig. 11. Catalytic performance of $\mathrm{Pd} / \mathrm{ZrO}_{2}, \mathrm{Pd} / \mathrm{SiO}_{2}$, and $\mathrm{Pd} / \mathrm{ZrO}_{2}-\mathrm{SiO}_{2}$ in $\mathrm{C}_{3} \mathrm{H}_{6}$ oxidation at a total flow rate of $200 \mathrm{ml} / \mathrm{min}\left(4000 \mathrm{ppm} \mathrm{CO}+1000 \mathrm{ppm} \mathrm{C}_{3} \mathrm{H}_{6}+500 \mathrm{ppm} \mathrm{NO}+10 \% \mathrm{O}_{2}+5 \% \mathrm{H}_{2} \mathrm{O}\right.$ + Ar balance) over fresh and hydrothermally aged catalysts. 

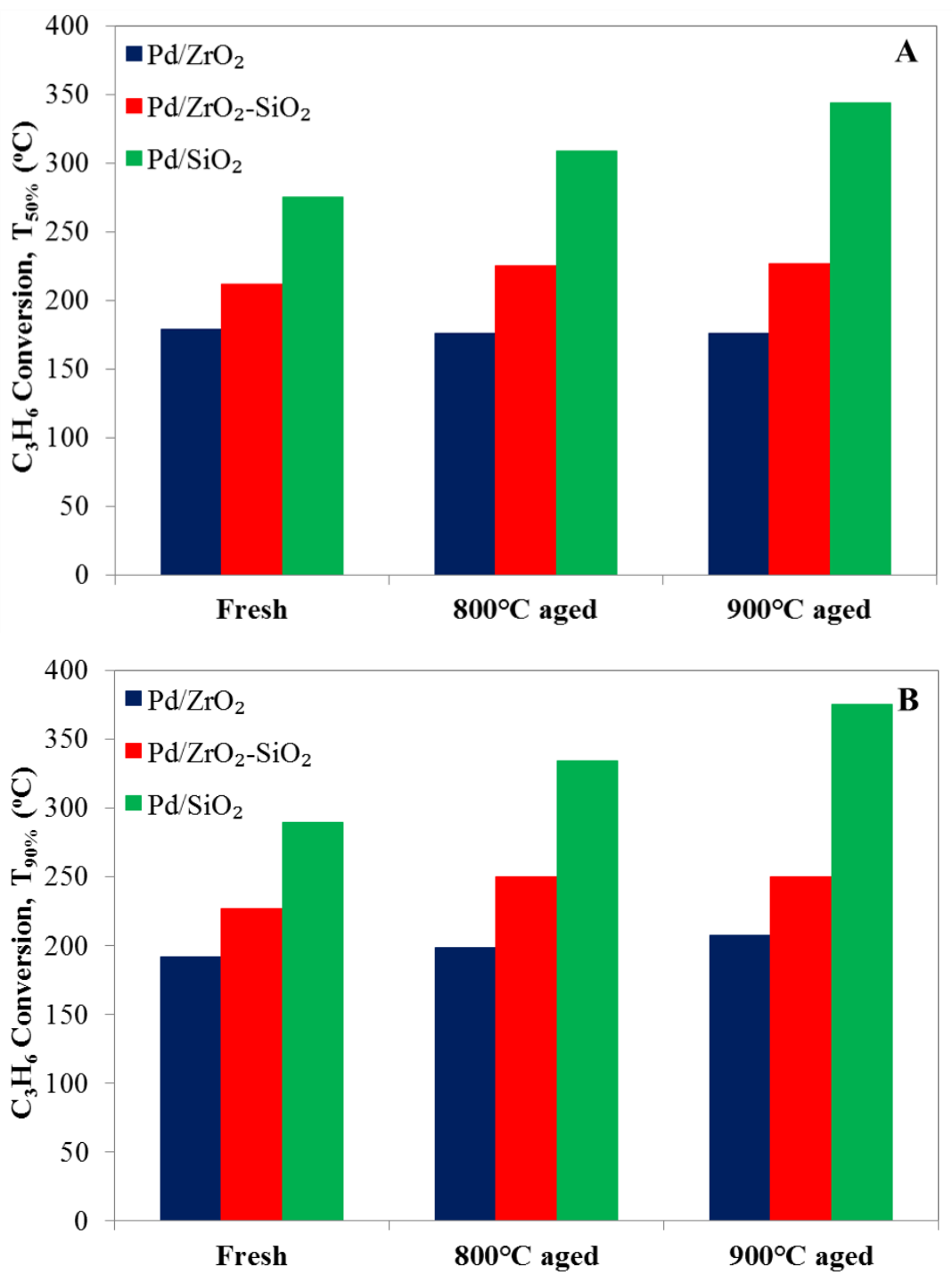

Fig. 12. Comparison of $\mathrm{C}_{3} \mathrm{H}_{6}$ conversion $T_{50 \%}$ (A) and $T_{90 \%}(\mathrm{~B})$ for $\mathrm{Pd} / \mathrm{ZrO}_{2}, \mathrm{Pd} / \mathrm{SiO}_{2}$ and $\mathrm{Pd} / \mathrm{ZrO}_{2}-\mathrm{SiO}_{2}$ at a total flow rate of $200 \mathrm{ml} / \mathrm{min}\left(4000 \mathrm{ppm} \mathrm{CO}+1000 \mathrm{ppm} \mathrm{C}_{3} \mathrm{H}_{6}+500 \mathrm{ppm}\right.$ $\mathrm{NO}+10 \% \mathrm{O}_{2}+5 \% \mathrm{H}_{2} \mathrm{O}+$ Ar balance) over fresh and hydrothermally aged catalysts. 

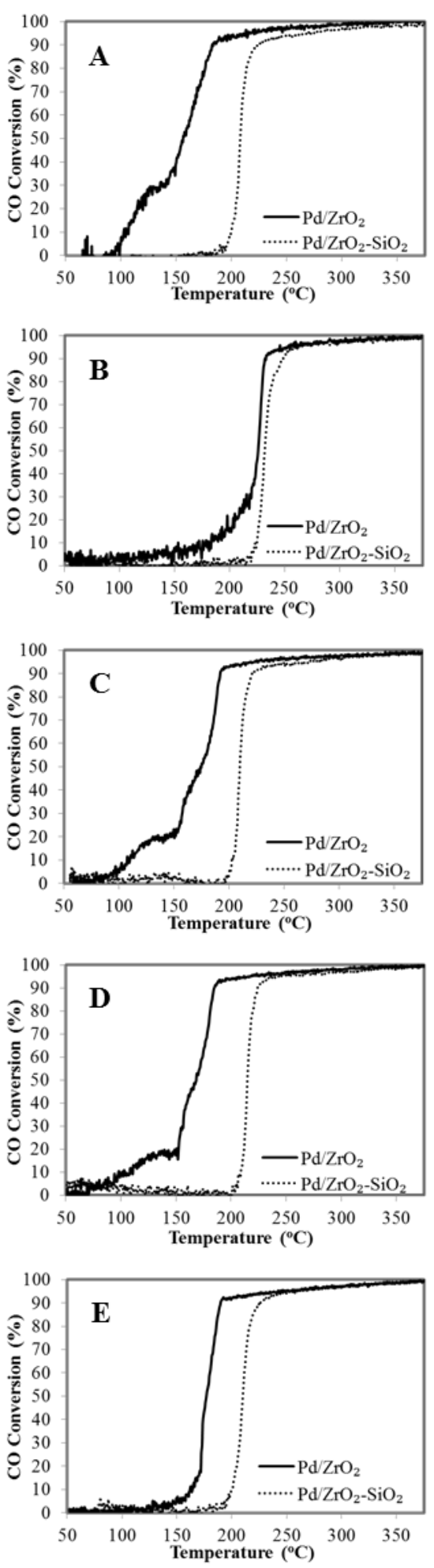

Fig. 13. Catalytic performance of $\mathrm{Pd} / \mathrm{ZrO}_{2}$ and $\mathrm{Pd} / \mathrm{ZrO}_{2}-\mathrm{SiO}_{2}$ in $\mathrm{CO}$ oxidation at a total flow rate of $200 \mathrm{ml} / \mathrm{min}\left(4000 \mathrm{ppm} \mathrm{CO}+1000 \mathrm{ppm} \mathrm{C}_{3} \mathrm{H}_{6}+500 \mathrm{ppm} \mathrm{NO}+10 \% \mathrm{O}_{2}+5 \% \mathrm{H}_{2} \mathrm{O}+\right.$ Ar balance) over fresh (A), sulfated (B) and desulfated at 600 (C), 700 (D) and $800^{\circ} \mathrm{C}$ (E) catalysts. 

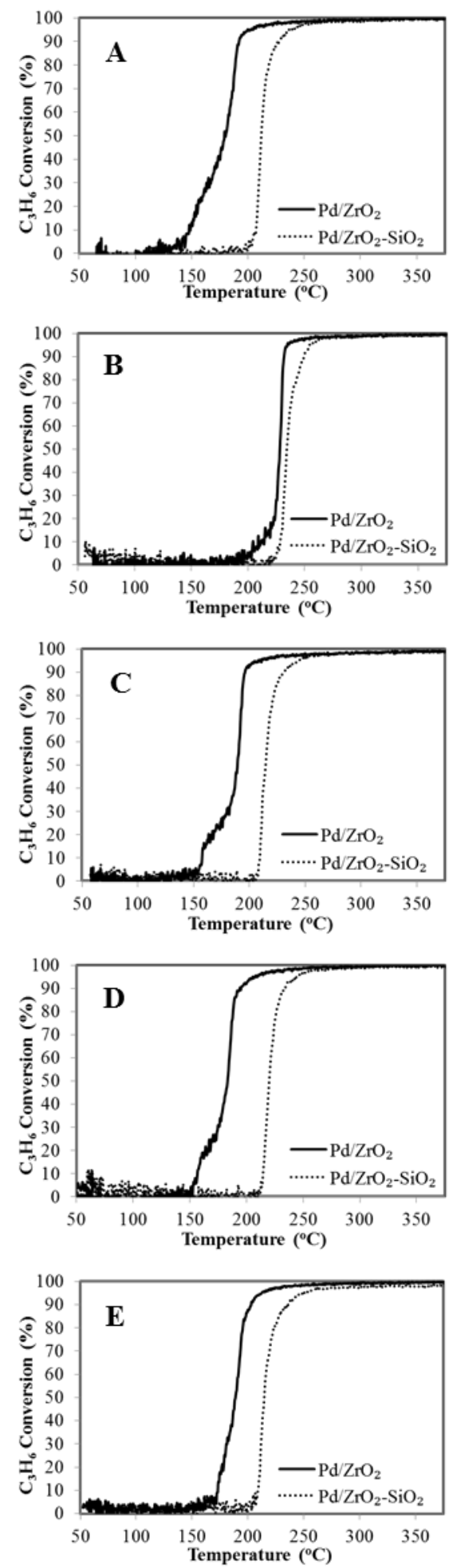

Fig. 14. Catalytic performance of $\mathrm{Pd} / \mathrm{ZrO}_{2}, \mathrm{Pd} / \mathrm{SiO}_{2}$, and $\mathrm{Pd} / \mathrm{ZrO}_{2}-\mathrm{SiO}_{2}$ in $\mathrm{C}_{3} \mathrm{H}_{6}$ oxidation at a total flow rate of $200 \mathrm{ml} / \mathrm{min}\left(4000 \mathrm{ppm} \mathrm{CO}+1000 \mathrm{ppm} \mathrm{C}_{3} \mathrm{H}_{6}+500 \mathrm{ppm} \mathrm{NO}+10 \% \mathrm{O}_{2}+5 \% \mathrm{H}_{2} \mathrm{O}\right.$ + Ar balance) over fresh (A), sulfated (B) and desulfated at 600 (C), 700 (D) and $800^{\circ} \mathrm{C}(\mathrm{E})$ catalysts. 

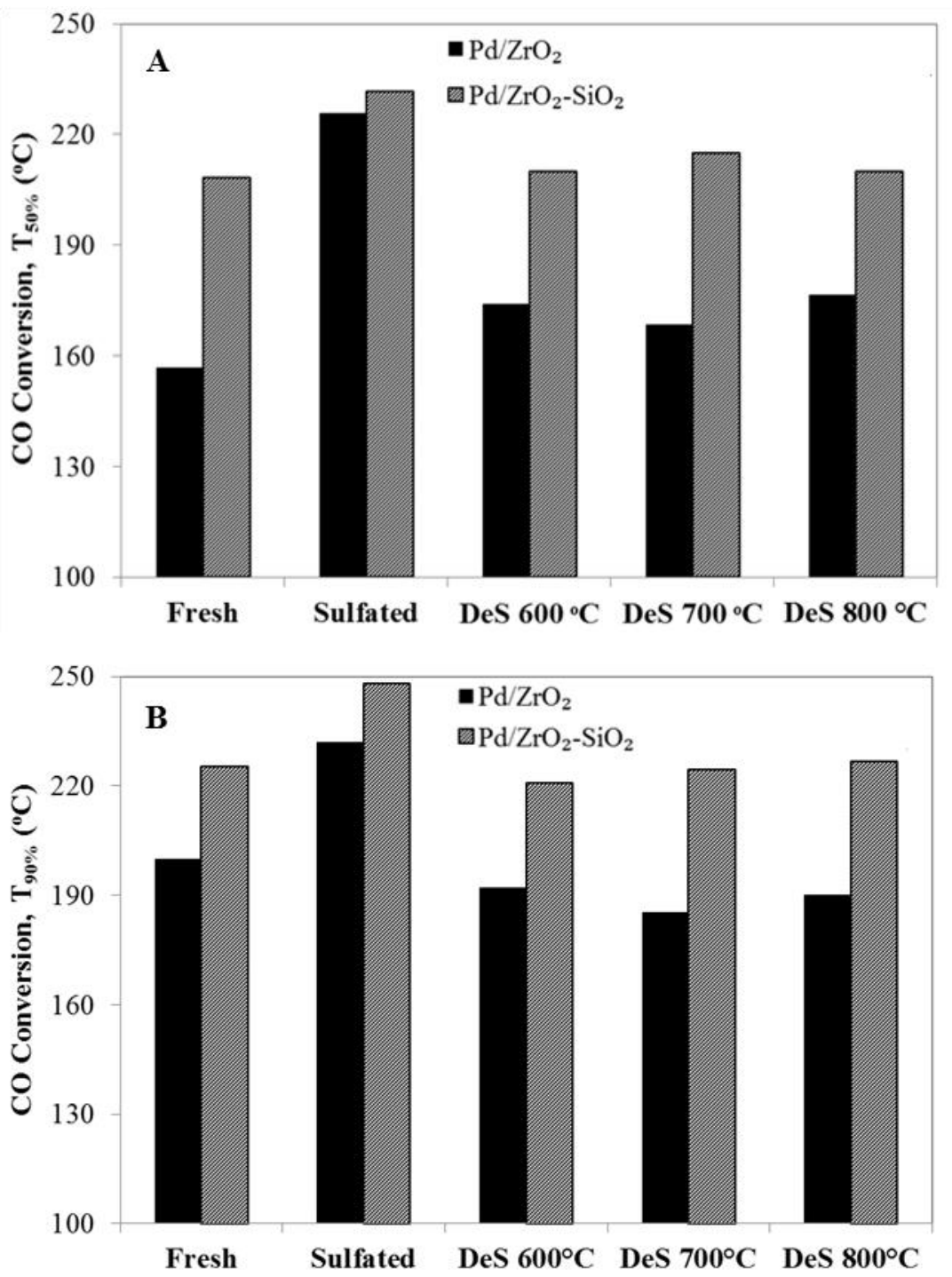

Fig. 15. Comparison of $\mathrm{CO}$ conversion $T_{50 \%}$ (A) and $T_{90 \%}$ (B) for $\mathrm{Pd} / \mathrm{ZrO}_{2}$ and $\mathrm{Pd} / \mathrm{ZrO}_{2}-\mathrm{SiO}_{2}$ catalysts at fresh, sulfated and desulfated (DeS) at various temperatures states at a total flow rate of $200 \mathrm{ml} / \mathrm{min}\left(4000 \mathrm{ppm} \mathrm{CO}+1000 \mathrm{ppm} \mathrm{C}_{3} \mathrm{H}_{6}+500 \mathrm{ppm} \mathrm{NO}+10 \% \mathrm{O}_{2}+5 \% \mathrm{H}_{2} \mathrm{O}+\right.$ Ar balance). 

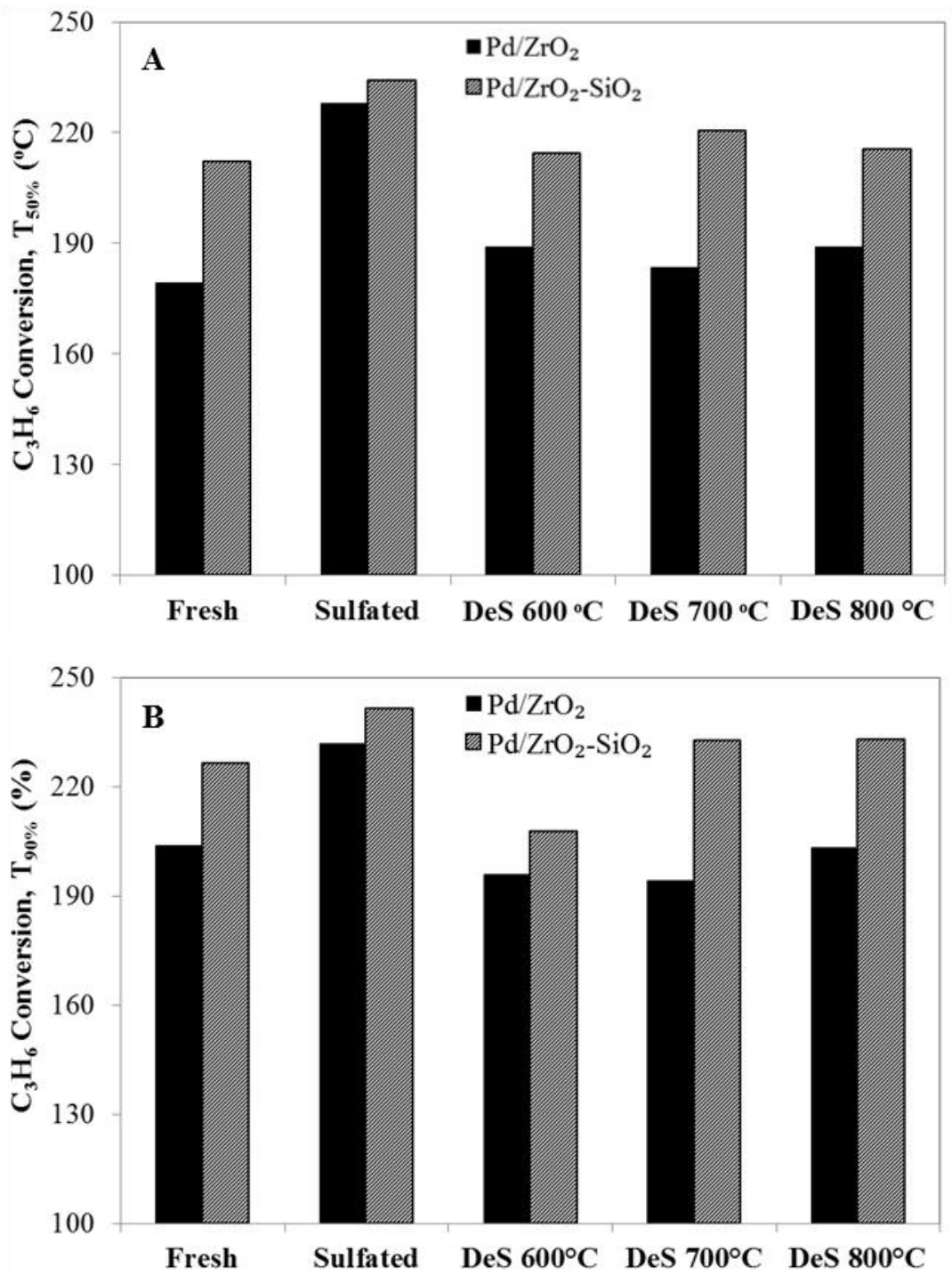

Fig. 16. Comparison of $\mathrm{CO}$ conversion $T_{50 \%}$ (A) and $T_{90 \%}$ (B) for $\mathrm{Pd} / \mathrm{ZrO}_{2}$ and $\mathrm{Pd} / \mathrm{ZrO}_{2}-\mathrm{SiO}_{2}$ catalysts at fresh, sulfated and desulfated (DeS) at various temperatures states at a total flow rate of $200 \mathrm{ml} / \mathrm{min}\left(4000 \mathrm{ppm} \mathrm{CO}+1000 \mathrm{ppm} \mathrm{C}_{3} \mathrm{H}_{6}+500 \mathrm{ppm} \mathrm{NO}+10 \% \mathrm{O}_{2}+5 \% \mathrm{H}_{2} \mathrm{O}+\right.$ Ar balance). 
- Pd particle

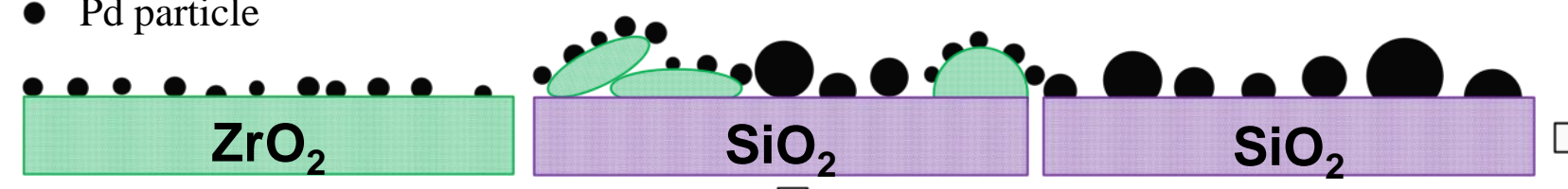

TEM images and Pd particle size distributions

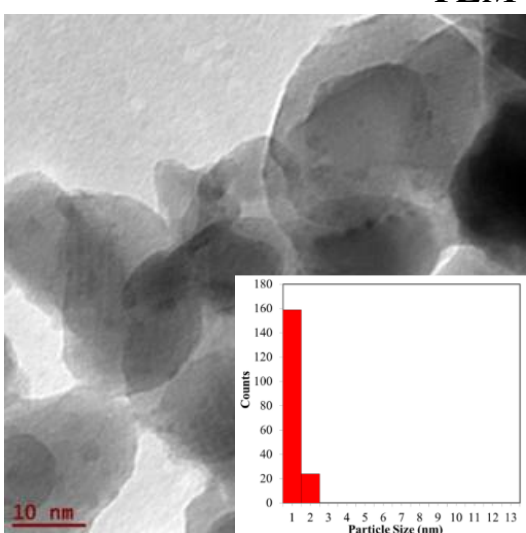

1 wt. $\% \mathrm{Pd} / \mathrm{ZrO}_{2}$

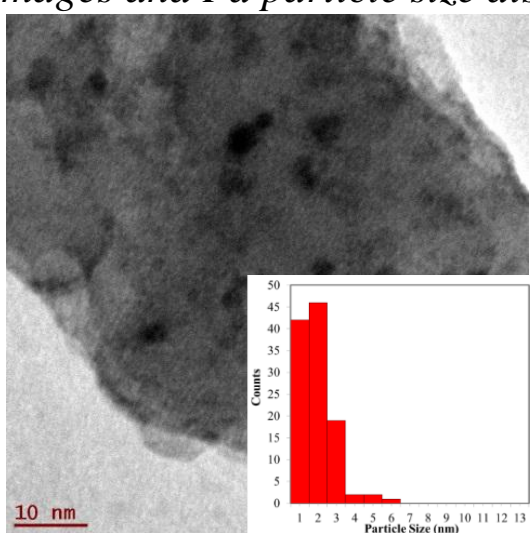

1 wt.\% $\mathrm{Pd} / \mathrm{ZrO}_{2}-\mathrm{SiO}_{2}$

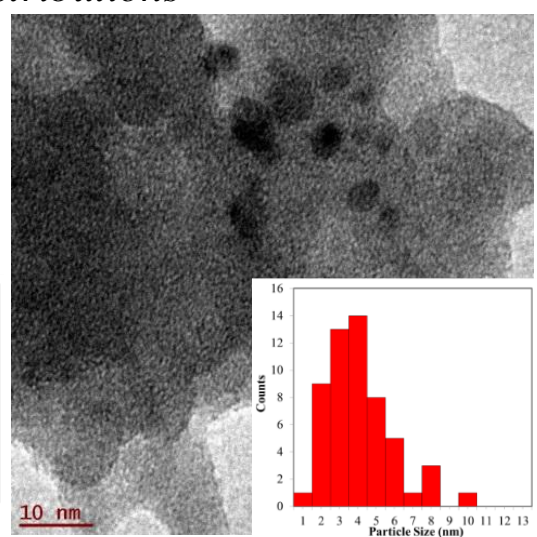

1 wt. $\% \mathrm{Pd} / \mathrm{SiO}_{2}$

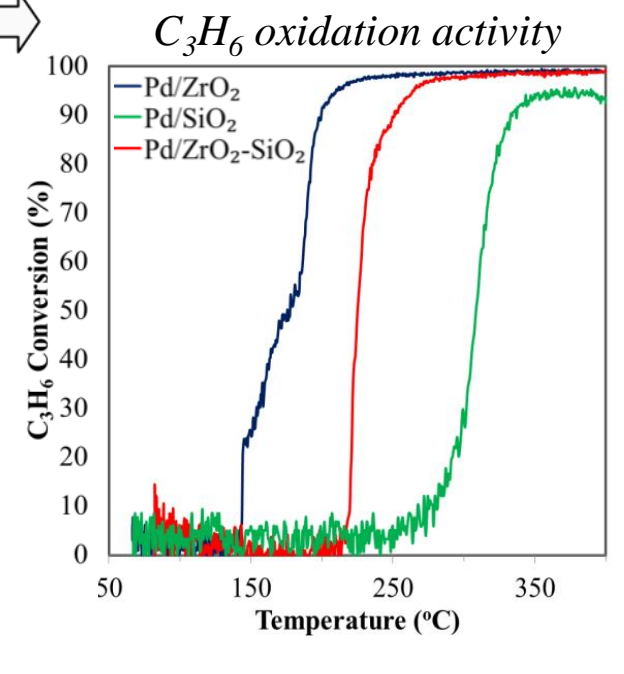

